\title{
Flavonoids as Human Intestinal $\alpha$-Glucosidase Inhibitors
}

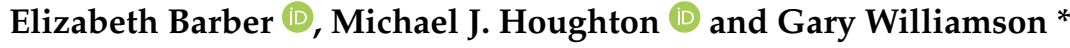

check for updates

Citation: Barber, E.; Houghton, M.J.; Williamson, G. Flavonoids as Human Intestinal $\alpha$-Glucosidase Inhibitors. Foods 2021, 10, 1939. https://doi.org/ $10.3390 /$ foods10081939

Academic Editors: Juscelino Tovar, Anne Nilsson and Oswaldo Hernandez-Hernandez

Received: 27 July 2021

Accepted: 16 August 2021

Published: 20 August 2021

Publisher's Note: MDPI stays neutral with regard to jurisdictional claims in published maps and institutional affiliations.

Copyright: (c) 2021 by the authors. Licensee MDPI, Basel, Switzerland. This article is an open access article distributed under the terms and conditions of the Creative Commons Attribution (CC BY) license (https:/ / creativecommons.org/licenses/by/ $4.0 /)$.
Department of Nutrition, Dietetics and Food, Faculty of Medicine, Nursing and Health Sciences, School of Clinical Sciences, Monash University, BASE (Be Active Sleep Eat) Facility, 264 Ferntree Gully Road, Notting Hill, VIC 3168, Australia; elizabeth.barber@monash.edu (E.B.); michael.houghton@monash.edu (M.J.H.)

* Correspondence: gary.williamson1@monash.edu; Tel.: +61-39-9056649

\begin{abstract}
Certain flavonoids can influence glucose metabolism by inhibiting enzymes involved in carbohydrate digestion and suppressing intestinal glucose absorption. In this study, four structurallyrelated flavonols (quercetin, kaempferol, quercetagetin and galangin) were evaluated individually for their ability to inhibit human $\alpha$-glucosidases (sucrase, maltase and isomaltase), and were compared with the antidiabetic drug acarbose and the flavan-3-ol(-)-epigallocatechin-3-gallate (EGCG). Cellfree extracts from human intestinal Caco-2/TC7 cells were used as the enzyme source and products were quantified chromatographically with high accuracy, precision and sensitivity. Acarbose inhibited sucrase, maltase and isomaltase with $\mathrm{IC}_{50}$ values of $1.65,13.9$ and $39.1 \mu \mathrm{M}$, respectively. A similar inhibition pattern, but with comparatively higher values, was observed with EGCG. Of the flavonols, quercetagetin was the strongest inhibitor of $\alpha$-glucosidases, with inhibition constants approaching those of acarbose, followed by galangin and kaempferol, while the weakest were quercetin and EGCG. The varied inhibitory effects of flavonols against human $\alpha$-glucosidases depend on their structures, the enzyme source and substrates employed. The flavonols were more effective than EGCG, but less so than acarbose, and so may be useful in regulating sugar digestion and postprandial glycaemia without the side effects associated with acarbose treatment.
\end{abstract}

Keywords: maltase; sucrase; isomaltase; HPAE-PAD; polyphenols; quercetin; quercetagetin; kaempferol; galangin; acarbose

\section{Introduction}

One of the earliest signs of type 2 diabetes (T2D) is elevated and erratic postprandial glycaemia that promotes oxidative stress at various sites within the body [1]. Controlling postprandial glycaemia is an important strategy in the management of T2D. One way is by slowing down carbohydrate digestion and glucose absorption in the intestine via the inhibition of salivary/pancreatic $\alpha$-amylases and membrane-bound brush-border $\alpha$-glucosidases.

There are four relevant types of digestive $\alpha$-glucosidases in humans, maltase ( $\alpha$ 1,4-glucosidase; EC 3.2.1.20), glucoamylase (exo-1,4- $\alpha$-glucosidase; EC 3.2.1.3), sucrase ( $\alpha$-glucohydrolase; EC 3.2.1.48) and isomaltase (oligo-1,6-glucosidase or $\alpha$-dextrinase; EC 3.2.1.10). Maltase and glucoamylase have a unique, high $\alpha-1,4$ hydrolytic activity for longer chain maltooligosaccharides to produce glucose [2], and are referred to as maltase/glucoamylase (MGAM) [3]. Sucrase-isomaltase (SI) is synthesized as a single glycoprotein chain in intestinal cells [4], and then cleaved into individual sucrase and isomaltase domains that reassociate non-covalently. Sucrase hydrolyses $\alpha-1,2$-glycosidic bonds in sucrose to produce glucose and fructose. Isomaltase is the only enzyme able to hydrolyze the $\alpha$-1,6-glycosidic linkage in $\alpha$-limit dextrins to produce glucose. MGAM and SI complexes are located along the entire small intestine [5,6] and function to catalyze the production of glucose and fructose from disaccharides, dextrins and dietary polysaccharides. Glucose and fructose pass across intestinal cell membranes via glucose transporters (GLUTs), mainly sodium-glucose transport protein-1 (SGLT1) and glucose transporters -2 
and -5 (GLUT2, GLUT5). The pathway of carbohydrate hydrolysis and absorption in the intestine is summarized in Figure 1. Rapidly digested and absorbed glucose in the intestine results in a sharp increase in plasma glucose, which is regulated by insulin-stimulated uptake of glucose into tissues.

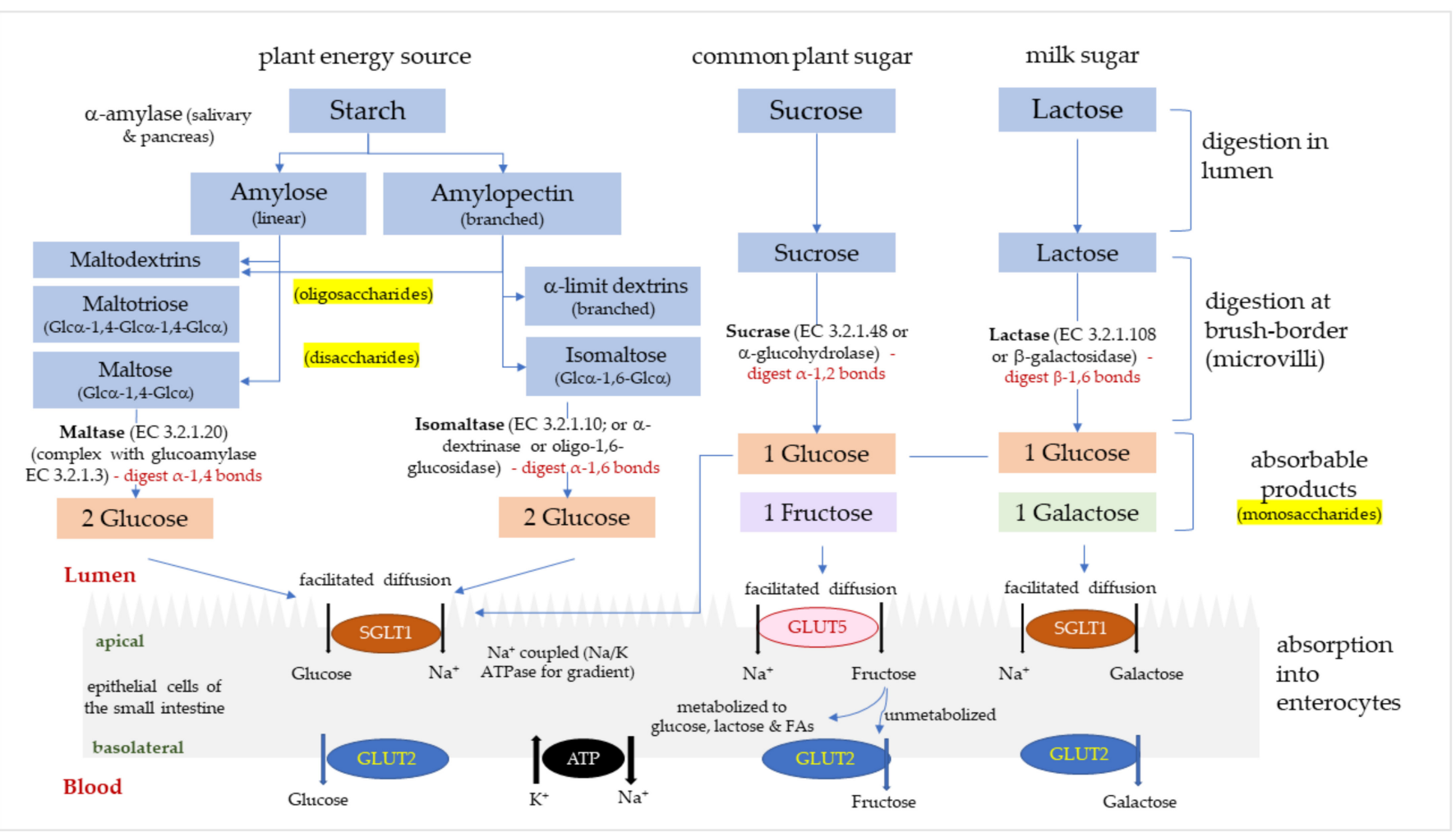

Figure 1. The digestion and absorption of starch and sugar in the small intestine. Glucose, fructose and galactose are absorbed into enterocytes via glucose transporters (GLUTs); sodium-glucose transport protein-1 (SGLT1) and glucose transporters -2 and -5 (GLUT2, GLUT5).

The most commonly used FDA-approved pharmaceutical $\alpha$-glucosidase inhibitor is acarbose, a fermented product from Actinoplanes species [7] that is low-risk and nontoxic [8,9], but is associated with uncomfortable side effects such as bloating, cramping, flatulence and abdominal pain [10], and drug-intolerance with chronic treatment [11]. Several potent $\alpha$-glucosidase inhibitors from plant sources have been identified and have received great attention from the scientific community worldwide as they possess no evident side effects $[12,13]$. Among them were flavonoids, the most extensively studied compounds as natural antidiabetic agents, associated with a reduction in risk of diabetes in humans, animals and in vitro models $[14,15]$. Food-derived flavonoids show extremely low toxicity [16-18].

Flavonoids are found ubiquitously in plants and represent $\sim 60 \%$ of all dietary (poly) phenolic compounds $[19,20]$. Flavonols, a sub-class of flavonoids, are present in onions, kale, apples, berries, leeks and broccoli [19]. Some flavonols excreted in urine can be used as biomarkers of flavonol intake and are significantly associated with a lower T2D risk [21]. Many flavonoids extracted from plants inhibit $\alpha$-amylase and $\alpha$-glucosidases activities in vitro and improved postprandial glycaemia in diabetic animal models and limited human studies [22,23]. Very few studies have reported on the inhibition of isomaltase, however. The disaccharide isomaltose is rarely present in nature but is commonly added as low-caloric food sweeteners in industrial-scale production [24,25], or produced from amylopectin hydrolysis to $\alpha$-limit dextrins. Studies assessing the isomaltase inhibitory potential by flavonoids and acarbose are therefore of interest. 
Unfortunately, many enzyme inhibition studies have been conducted using $\alpha$-glucosidases from yeast or bacteria, with fewer studies using human intestinal enzymes. The inhibition of yeast and human $\alpha$-glucosidases is very different, specific to the type of substrate, as reported for maltose [2]. Here we used Caco-2 cells, originating from human colon cancer cells, which form monolayers that differentiate to produce apical microvilli with high expression of maltase and sucrase. The Caco-2/TC7 clone specifically expresses high SI levels at 19-25 days post-confluence [24,26]. Using an enzyme preparation from these cells, we have evaluated sucrase, maltase and isomaltase inhibition by several flavonols and compared them to acarbose and (-)-epigallocatechin-3-gallate (EGCG), a flavan-3-ol known for its inhibitory activity on sucrase and maltase of various sources [27]. These natural compounds may provide promising alternatives for diabetes management with no undesirable side effects.

\section{Materials and Methods}

\subsection{Reagents and Instruments}

Buffer components, sugar substrates and standards, and most inhibitors (acarbose, galangin, kaempferol and EGCG) were purchased from Sigma-Aldrich Corp., Merck (St. Louis, MO, USA), with purity $>98 \%$. Quercetagetin was purchased from EMD Millipore, Merck (Burlington, MA, USA) and quercetin was purchased from Extrasynthese (Genay, France). Maltose monohydrate, sucrose and isomaltose were used as substrates for the enzyme assay, and together with fructose and glucose, were used as sugar standards for the chromatographic analyses. All other chemicals were of analytical grade and also purchased from Sigma-Aldrich, unless specified otherwise.

The Dionex ${ }^{\mathrm{TM}}$ Integrion ${ }^{\mathrm{TM}} \mathrm{HPIC}^{\mathrm{TM}}$ (High Performance Ion Chromatography) system was used for High-Performance Anion-Exchange chromatography with Pulsed Amperometric Detection (HPAE-PAD) (Thermo Fisher Scientific Inc., Waltham, MA, USA) for the separation and analysis of sugars. A PHERAstar FS plate reader (BMG Labtech, Ortenberg, Germany) was used for measuring absorbance in the total protein assay. High-purity $(18.2 \mathrm{~m} \Omega / \mathrm{cm}) \mathrm{H}_{2} \mathrm{O}$ supplied by a MilliQ system (Millipore) was used throughout.

\subsection{HPAE-PAD Instrumentation and Chromatographic Conditions}

Disaccharides and monosaccharides were analyzed by HPAE-PAD on the Dionex ${ }^{\mathrm{TM}}$ Integrion $^{\mathrm{TM}} \mathrm{HPIC}^{\mathrm{TM}}$ system (Thermo Fisher Scientific). Separation of the carbohydrates was achieved on a CarboPac PA210 column $(2 \times 150 \mathrm{~mm})$, preceded by a CarboPac PA210 Guard column $(2 \times 30 \mathrm{~mm})$, with the column and compartment temperatures maintained at $30^{\circ} \mathrm{C}$ and $20^{\circ} \mathrm{C}$, respectively. Eluent was generated using a Dionex ${ }^{\mathrm{TM}} \mathrm{EGC}$ $500 \mathrm{KOH}$ eluent generator cartridge with Dionex ${ }^{\mathrm{TM}}$ continuously regenerated-anion trap column 600, with eluent concentration following a multistep gradient: $12 \mathrm{mM}$ for $12 \mathrm{~min}$, $100 \mathrm{mM}$ for $8 \mathrm{~min}$ and $12 \mathrm{mM}$ for $12 \mathrm{~min}$, at a flow rate of $0.2 \mathrm{~mL} / \mathrm{min}$ and with a sample injection volume of $2.5 \mu \mathrm{L}$. Detection was performed using a gold working electrode and $\mathrm{AgCl}$ reference electrode at $\mathrm{pH} \sim 12.0$, with a collection rate of $2.00 \mathrm{~Hz}$ using the "Gold, Carbo, Quad" waveform. The total run time per sample was $32 \mathrm{~min}$, with $3 \mathrm{~min}$ allowed between analyses for sample injection by autosampler. A wash injection of only $\mathrm{H}_{2} \mathrm{O}$ while following the same multistep eluent gradient was performed at the end of every batch (12-14 samples). All injections were performed in duplicate and peak identification was achieved by comparing retention times to the standards. Dionex ${ }^{\mathrm{TM}}$ Chromeleon $^{\mathrm{TM}}$ 7 Chromatography Data System, version 7.2.9 (Thermo Fisher Scientific, Waltham, MA, USA), was used to process the chromatograms, ensuring peaks were suitably integrated before recording peak area. Sugars were quantified from peak areas using standard curves, with the standards prepared in the same buffer as the samples.

\subsection{Substrate, Inhibitor/Flavonoid and Sample Preparation}

Stock solutions ( $250 \mathrm{mM})$ of sucrose, maltose and isomaltose (substrates), plus glucose and fructose (standards only), were prepared in sodium phosphate buffer (SPB, $10 \mathrm{mM}$, 
$\mathrm{pH}$ 7.0). Stock solutions of acarbose $(1 \mathrm{mM})$ and all flavonoids $(10 \mathrm{mM})$ were prepared by dissolving in their respective solvents, stored at $-20^{\circ} \mathrm{C}$ and used within 2 weeks. Acarbose and EGCG were prepared in $\mathrm{H}_{2} \mathrm{O}$, quercetin and quercetagetin were prepared in DMSO, while kaempferol and galangin were dissolved in absolute ethanol. The maximum working concentrations for each compound was pre-determined before enzymatic reaction assay to ensure no precipitation occurred in the system. Compared to acarbose and EGCG, lower solubility of tested flavonols was expected due to their structural differences, where compounds with less than $100 \mu \mathrm{g} / \mathrm{mL}$ solubility were considered poorly soluble, as reported previously [28,29]. Inhibitors were tested at various concentrations: acarbose $(0.1-100 \mu \mathrm{M})$, EGCG $(5-1500 \mu \mathrm{M})$, quercetin $(20-200 \mu \mathrm{M})$, quercetagetin $(1-50 \mu \mathrm{M})$, kaempferol $(5-40 \mu \mathrm{M})$ and galangin $(1-25 \mu \mathrm{M})$. The flavonols were tested up to their maximum soluble concentrations. Working solutions were prepared fresh at various concentrations in SPB buffer immediately before assaying. The maximum concentrations $(v / v)$ of DMSO were $\leq 2 \%$ and $\leq 0.5 \%$ for quercetin and quercetagetin, respectively, and ethanol was $\leq 0.5 \%$ for kaempferol and galangin. The solvents did not affect enzyme activity, as demonstrated by vehicle controls. Cell-free extracts (CFE) were prepared as described in Section 2.6 and used as the enzyme source.

All prepared standards and assay samples, for both method validation and post-assay quantification, underwent the same treatment prior to injection on the HPAE-PAD system. All were deproteinated by mixing with an equal volume of acetonitrile, vortexed for $30 \mathrm{~s}$ and centrifuged at $17,000 \times g, 15 \mathrm{~min}$ at $4{ }^{\circ} \mathrm{C}$. The resulting supernatants were then diluted at least $10 \times$ in $\mathrm{H}_{2} \mathrm{O}$ (maximum final acetonitrile concentration of $5 \%(v / v)$ ). Additionally, all standards and samples containing enzyme and substrates were filtered through $0.2 \mu \mathrm{M}$ polyether sulfone (PES) filters (Sartorius, Göttingen, Germany). All standards, samples and blanks were kept at $4-8{ }^{\circ} \mathrm{C}$ until analysis by HPAE-PAD, as described in Section 2.2, was complete.

\subsection{Validation Parameters for Quantification}

The HPAE-PAD method for the quantification of glucose, sucrose, fructose, isomaltose and maltose was set up based on our previously published method [30], but with improved sensitivity and run time. The method was validated for specificity, linearity, sensitivity, precision, and accuracy as percent extraction recovery, according to the guidelines issued by the U.S. Food and Drug Administration (FDA) 2018 [31] and International Conference on Harmonisation (ICH) 2005 [32].

\subsubsection{Specificity and Matrix Effect}

Specificity was determined by evaluating any endogenous interferences from the CFE. A comparison study was conducted on chromatograms of a blank incubated CFE matrix sample (CFE/enzyme only), CFE incubation sample with inhibitors (without substrate), CFE incubation sample with a substrate (without inhibitor), individual inhibitors only and blank assay solvent (DMSO and ethanol $(v / v<2 \%)$ ). Blank samples spiked with a known amount of maltose, sucrose and isomaltose served as reference. The matrix effect was evaluated by comparing the analytical response of sugar spikes in SPB to those in $\mathrm{H}_{2} \mathrm{O}$, to ensure accurate calibration plots were constructed.

\subsubsection{Linearity}

The linearity of the HPAE-PAD method was evaluated by a calibration curve constructed by plotting concentrations of standards against their peak areas within the determined limits of detection and quantification (LOD and LOQ, respectively; see below). Six different concentrations of maltose, sucrose and isomaltose $(0.1,0.5,1.0,2.5,5.0$ and $10.0 \mu \mathrm{g} / \mathrm{mL}$ ) were prepared in assay incubation buffer or distilled water and measured in triplicate on four different days, giving a total of twelve replicates to construct the curve. Linearity was evaluated by calculating a regression line by the least-squares method, deter- 
mining a linear equation (Equation (1)), where $y=$ peak area, $x=$ concentration, $a=$ slope, $\mathrm{b}=$ intercept, and $\mathrm{R}^{2}$ for each standard [33].

$$
\mathrm{y}=\mathrm{ax}+\mathrm{b}
$$

\subsubsection{Sensitivity}

The sensitivity of the method was evaluated by determining the LOD and LOQ using data generated from the calibration curve. LOD and LOQ were measured using the SD of the y-intercept and the slope of the calibration curve, as shown in Equations (2) and (3) below, where $\mathrm{SD}_{\mathrm{y}-\mathrm{int}}$ is the standard deviation of the $\mathrm{y}$-intercept and $\mathrm{S}$ is the calibration curve slope. Both LOD and LOQ were expressed as analyte concentration $(\mu \mathrm{M})$ :

$$
\begin{aligned}
& \mathrm{LOD}=3.3 \times \frac{\mathrm{SD}_{\mathrm{y}-\mathrm{int}}}{\mathrm{S}} \\
& \mathrm{LOQ}=10 \times \frac{\mathrm{SD}_{\mathrm{y}-\mathrm{int}}}{\mathrm{S}}
\end{aligned}
$$

\subsubsection{Precision}

Precision (repeatability and reproducibility) was determined through the analysis of intra- and inter-day assay using standards in SPB quantification buffer. Intra-assay precision was assessed by measuring six concentrations of each standard measured in triplicate on the same day, in one laboratory by one person. Inter-assay precision was carried out by measuring the same concentrations of standards measured (in triplicate) over four different days by two analysts in the same laboratory. Precision was expressed as percent coefficient of variance (\%CV), according to Equation (4), calculated as:

$$
\% \mathrm{CV}=\frac{\text { standard deviation }}{\text { sample mean }} \times 100
$$

\subsubsection{Accuracy as Extraction Recovery}

As standard reference material was not used, accuracy was determined using the extraction recovery calculated by comparing the analytical response of two different concentrations of substrates spiked pre-assay to the values recovered post-assay in triplicates. The accuracy was calculated following Equation (5) as below:

$$
\text { Extraction Recovery }(\%)=\frac{C_{\text {measured }}}{C_{\text {standard }}} \times 100
$$

where $C_{\text {measured }}=$ measured concentration calculated from the calibration curve $(\mu \mathrm{M})$; $\mathrm{C}_{\text {standard }}=$ real (prepared) concentration of the standard solution $(\mu \mathrm{M})$, which was used in the calculation of the percent relative error (\%RE), as shown in Equation (6) below:

$$
\text { Relative Error accuracy }(\% R E)=\frac{C_{\text {measured }}-C_{\text {standard }}}{C_{\text {standard }}}
$$

\subsection{Cell Culture}

Caco-2/TC7 cells, originating from human colon adenocarcinoma, were a kind donation from Dr Rousset, INSERM U505, Paris, France. Cells were seeded at $\sim 1 \times 10^{6}$ cells/T75 culture flask, maintained at $37{ }^{\circ} \mathrm{C}$ in an atmosphere of $10 \% \mathrm{CO}_{2} / 90 \%$ air at a relative humidity in Dulbecco's modified Eagle's medium (DMEM) with high glucose $(4.5 \mathrm{~g} / \mathrm{L})$ (Sigma-Aldrich, St. Louis, MO, USA). The medium was supplemented with $2 \%(v / v)$ Glutamax (Invitrogen, Thermo Fisher Scientific, Waltham, MA, USA), 1\% $(v / v)$ nonessential amino acids, $1 \%(v / v)$ penicillin-streptomycin $(100 \mathrm{IU} / \mathrm{mL}$ penicillin and $100 \mathrm{ug} / \mathrm{mL}$ streptomycin) and $20 \%(v / v)$ heat-inactivated foetal bovine serum (FBS; $56{ }^{\circ} \mathrm{C}, 30 \mathrm{~min}$ ) (Gibco, Thermo Fisher Scientific, Waltham, MA, USA). Cells were passaged with $0.25 \%$ 
trypsin-EDTA before reaching $~ 70 \%$ confluence. Cells were used for experiments during passages 31-34 and were maintained until 21 days post-confluence, with medium routinely changed every $2-3$ days, to differentiate. On day 21 , cells were thoroughly washed twice with ice-cold PBS and harvested into ice-cold PBS containing 1\% protease inhibitor cocktail (Sigma-Aldrich, St. Louis, MO, USA). Following centrifugation at $200 \times g, 10 \mathrm{~min}$ at $4{ }^{\circ} \mathrm{C}$, the supernatant was discarded and cell pellets were frozen immediately at $-80^{\circ} \mathrm{C}$ until required for the enzyme assay.

\subsection{Enzyme Activity Assay}

To mimic intestinal digestion, an in vitro assay using Caco-2/TC7 cell extracts containing sucrase, maltase and isomaltase was conducted. Frozen cells were thawed, $1 \mathrm{~mL}$ ice-cold SPB added and then passed through a 21-G needle 15-20 times. The lysate was centrifuged at $14,000 \times g, 10 \mathrm{~min}$ at $4{ }^{\circ} \mathrm{C}$ and the supernatant containing cell-free extract (CFE) collected. Total protein concentration in the CFEs was determined by Bradford assay [34,35], using the Pierce Coomassie Bradford reagent and BSA standards (Thermo Fisher Scientific, Waltham, MA, USA).

Assay mixtures, total volume $250 \mu \mathrm{L}$, containing CFE (final protein concentration at $0.1-0.35 \mathrm{mg} / \mathrm{mL}$ ), with or without various concentrations of inhibitors/flavonoids, were prepared and kept on ice. The enzyme reaction was initiated by the addition of $\geq 20 \mathrm{mM}$ sucrose, maltose or isomaltose and immediately incubating in a $37^{\circ} \mathrm{C}$ water bath for $10 \mathrm{~min}$ (or various time points during method setup and validation). Following incubation, the enzyme activity was terminated by incubating in a $96^{\circ} \mathrm{C}$ water bath for a further $10 \mathrm{~min}$. A positive control without any added inhibitor/flavonoid was simultaneously tested in each batch, and negative controls without enzymes or substrates were also assayed to evaluate the stability of the inhibitors/compounds. Samples were prepared for HPAE-PAD analysis as described in Section 2.3. Specific enzyme activities were determined (U/mg CFE protein) and expressed as a percentage of control enzyme activities accordingly.

\subsubsection{Optimization of Assay Conditions and Enzyme Kinetics}

Preliminary assays to optimize the substrate and enzyme concentrations and incubation time were performed to ensure enzyme kinetic experiments were carried out under initial linear velocity conditions (substrate depletion $<10 \%$ ). CFE protein concentration was tested, and specific activities found to be linear, at $0.10-0.35 \mathrm{mg} / \mathrm{mL}$ (Table 1), with substrates tested at $10-80 \mathrm{mM}$ for maltase and $5-50 \mathrm{mM}$ for sucrase and isomaltase, while incubation times were tested for 10-60 min. Michaelis-Menten and Lineweaver-Burk plots were used to obtain the kinetic parameters of the digestive enzymes, using GraphPad Prism 8.0 software (GraphPad Software, San Diego, CA, USA) (Table 2).

Table 1. Linear regression showing the velocity of enzyme activities in Caco-2/TC7 cell-free extracts (CFE) $(n=3)$.

\begin{tabular}{cccc}
\hline Parameters & Sucrase & Maltase & Isomaltase \\
\hline Substrate concentration $(\mathrm{mM})$ & 20 & 20 & 20 \\
\hline $\begin{array}{c}\text { CFE protein concentration } \\
(\mathrm{mg} / \mathrm{mL})\end{array}$ & $0-0.35$ & $0-0.25$ & $0-0.30$ \\
\hline $\begin{array}{c}\text { Specific activity } \\
\text { (mean mU/mg } \pm \mathrm{SD})\end{array}$ & $145 \pm 31^{1}$ & $1197 \pm 183^{1}$ & $298 \pm 37$ \\
\hline Linear equation & $y=0.18 x+0.001$ & $y=0.94 x+0.0002$ & $y=0.63 x+0.007$ \\
\hline $\mathrm{R}^{2}$ & 0.9878 & 0.9995 & 0.9859 \\
\hline
\end{tabular}

${ }^{1}$ Reported previously as $130 \pm 4 \mathrm{mU} / \mathrm{mg}$ or $725 \pm 36 \mathrm{mU} / \mathrm{mg}$ using $10 \mathrm{mM}$ sucrose or maltose, respectively, $\mathrm{CFE} \leq 0.64 \mathrm{mg} / \mathrm{mL}[27]$. 
Table 2. Enzyme kinetic constants from Michaelis-Menten and Lineweaver-Burk plots for sucrase, maltase and isomaltase in Caco-2/TC7 cell-free extracts (CFE) using substrates sucrose, maltose and isomaltose, respectively $(n=3)$. App = apparent.

\begin{tabular}{cccc}
\hline Parameters & Enzymes \\
\hline \multicolumn{4}{c}{ Sucrase (tested at one concentration) } \\
\hline CFE tested $(\mathrm{mg} / \mathrm{mL})$ & 0.25 \\
\hline App $\mathrm{K}_{\mathrm{m}}(\mathrm{mM})(95 \% \mathrm{CI})$ & $5.8(2.1-12.2)$ & \\
\hline $\mathrm{V}_{\max }(\mathrm{mmol} / \mathrm{min})(95 \% \mathrm{CI})$ & $0.039(0.031-0.045)$ & 0.30 \\
\hline \multicolumn{5}{c}{ Maltase (tested at multiple concentrations) } \\
\hline CFE tested $(\mathrm{mg} / \mathrm{mL})$ & 0.10 & 0.20 & $19.1(13.9-26.1)$ \\
\hline App $\mathrm{K}_{\mathrm{m}}(\mathrm{mM})(95 \% \mathrm{CI})$ & $8.8(6.4-11.7)$ & $11.6(8.8-14.9)$ & $1.04(0.93-1.17)$ \\
\hline $\mathrm{V}_{\max }(\mathrm{mmol} / \mathrm{min})(95 \% \mathrm{CI})$ & $0.35(0.33-0.38)$ & $0.64(0.59-0.69)$ & 0.30 \\
\hline \multicolumn{4}{c}{$\mathrm{Isomaltase}($ tested at multiple concentrations $)$} \\
\hline CFE tested $(\mathrm{mg} / \mathrm{mL})$ & 0.10 & 0.20 & $9.3(7.4-11.7)$ \\
\hline $\mathrm{V}_{\max }(\mathrm{mmol} / \mathrm{min})(95 \% \mathrm{CI})$ & $0.082(0.076-0.087)$ & $0.22(0.21-0.22)$ & $0.30(0.29-0.32)$ \\
\hline
\end{tabular}

The specific activities of sucrase and maltase were similar to those we reported previously [27]. Lower CFE concentrations $(0.25 \mathrm{mg} / \mathrm{mL}$ for sucrase and $0.1 \mathrm{mg} / \mathrm{mL}$ for maltase and isomaltase) were used to determine the substrate concentration required to achieve maximal catalytic efficiency or velocity of reaction $\left(\mathrm{V}_{\max }\right)$ (Table 2). Sucrase, maltase and isomaltase exhibited a linear production of glucose up to $40 \mathrm{~min}$ using $20 \mathrm{mM}$ maltose, sucrose and isomaltose, respectively. A 10 min incubation time was used in the inhibition assays to ensure reactions were in the initial linear velocity phase. Assays were performed using CFEs from biological triplicates.

\subsubsection{Inhibition by Acarbose and Flavonoids}

Using the optimal assay conditions, various concentrations of acarbose and flavonoids were tested. Controls (CFE and substrate only) were prepared by replacing the volume of inhibitor with SPB. Activities of sucrase, maltase and isomaltase were considered as $100 \%$ (or $0 \%$ inhibition) in the absence of an inhibitor. Compounds that exhibited enzyme inhibition of at least $15 \%, 25 \%$ and $50 \%$ were subjected to $\mathrm{IC}_{15}, \mathrm{IC}_{25}$ and $\mathrm{IC}_{50}$ value determination, respectively, or the maximum percentage of inhibition expressed. Estimation of inhibition values were determined in GraphPad Prism and the percentage of inhibition of the sample was calculated following Equation (7) below, where SA = specific activity:

$$
\text { Inhibition }(\%)=\frac{\mathrm{SA}_{\text {control }}-\mathrm{SA}_{\text {sample }}}{\mathrm{SA}_{\text {control }}} \times 100
$$

\subsection{Data Analysis}

Enzyme assays were performed at least once for CFEs from biological triplicates, with duplicate injections of each analyzed by HPAE-PAD. MS Excel (Microsoft, Redmond, WA, USA) was used for data processing and analysis. Final inhibition values were expressed as the percentage of control activity (\%). The $\mathrm{IC}_{15}, \mathrm{IC}_{25}$ and $\mathrm{IC}_{50}$ values were calculated based on the plots created using GraphPad, using the dose-response inhibition (log (inhibitor) vs. normalized response-variable slope) model. The same software was used to determine the apparent $K_{m}$ and $V_{\max }$ values under the enzyme-kinetic inhibition model, and for statistical analyses using non-parametric multiple comparisons tests. A difference was considered significant at $p<0.05$ for all comparisons. All data are expressed as the mean \pm SD or SEM, specified accordingly. 


\section{Results}

\subsection{Method Validation}

The potential inhibition of key human intestinal $\alpha$-glucosidases by flavonoids was evaluated. Initially, the analytical method was optimized and validated. Chromatograms for mixed sugar standards in $\mathrm{H}_{2} \mathrm{O}$ or in sodium phosphate assay buffer (SPB) were almost identical, with the same retention times and peak areas, demonstrating the absence of matrix effects (Figure 2a). Specificity was confirmed by comparing the retention times and peak areas of the sugars when run individually and as a mixture. The peak areas from mixed sugar standards prepared in SPB were used to plot standard curves $(0-10 \mu \mathrm{g} / \mathrm{mL})$, with excellent linearity for all sugars in this range (Figure 2b). The intercepts were not significantly different from zero $(p=0.225)$. LOD and LOQ for all five sugars were determined as a signal to noise ratio of 3:1 and 10:1, respectively. All sugar standards showed low LOD (ranging from $0.106 \mu \mathrm{M}$ for maltose to $0.619 \mu \mathrm{M}$ for fructose) and LOQ (ranging from $0.320 \mu \mathrm{M}$ for maltose to $1.876 \mu \mathrm{M}$ for fructose) (Table 3).

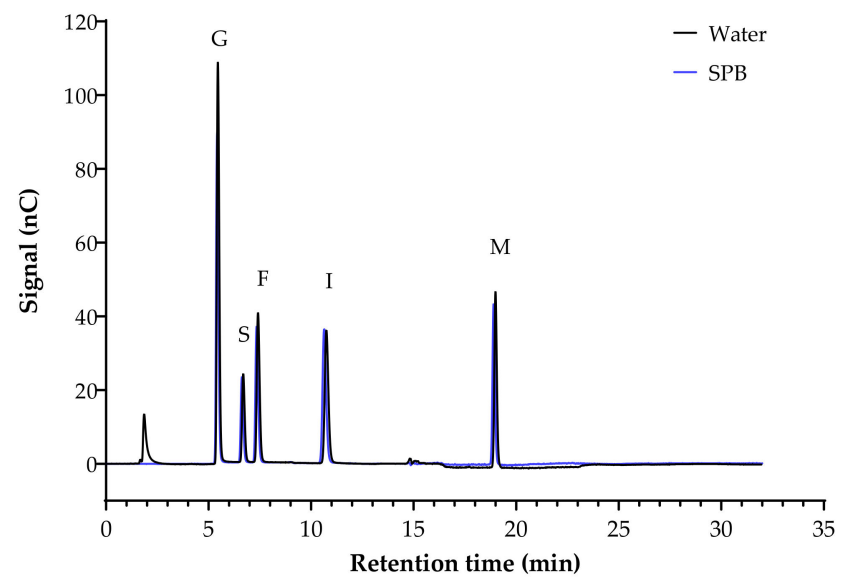

(a)

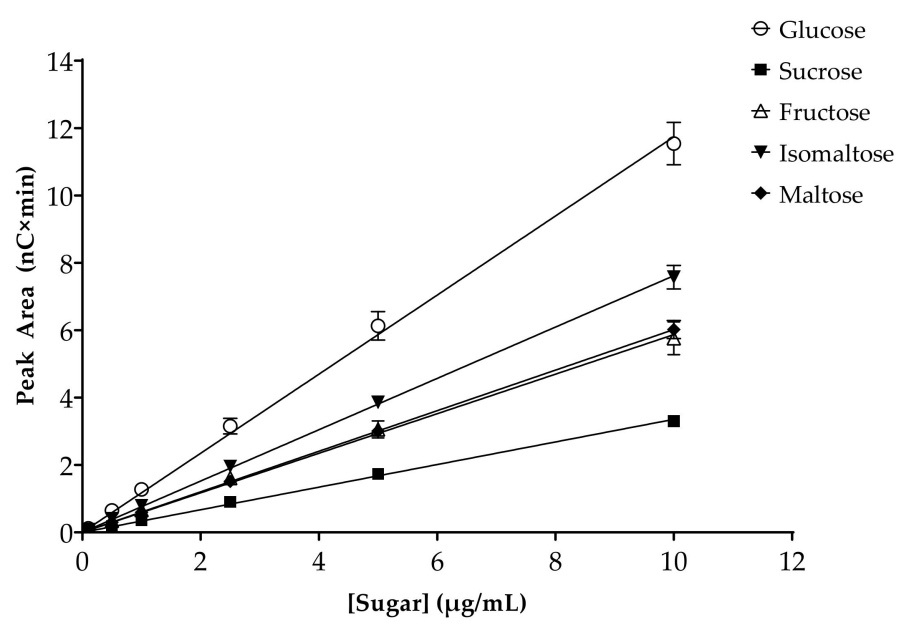

(b)

Figure 2. Separation of sugars, the substrates and products of the $\alpha$-glucosidase assays, by HPAEPAD ion chromatography. (a) Representative chromatogram of the mixed sugar standards in $\mathrm{H}_{2} \mathrm{O}$ (black line) and sodium phosphate buffer (SPB, blue line). Glucose (G), sucrose (S), fructose (F), isomaltose (I) and maltose (M) are at a concentration of $10 \mu \mathrm{g} / \mathrm{mL}$ each. Running conditions: $12 \mathrm{mM}$ $\mathrm{KOH}$ eluent for $12 \mathrm{~min}, 100 \mathrm{mM} \mathrm{KOH}$ eluent for $8 \mathrm{~min}, 12 \mathrm{mM} \mathrm{KOH}$ eluent for $12 \mathrm{~min}$ (run time $32 \mathrm{~min}$ per injection); flow rate, $0.2 \mathrm{~mL} / \mathrm{min}$; injection volume $2.5 \mu \mathrm{L}$; column and compartment temperature, $30{ }^{\circ} \mathrm{C}$ and $20^{\circ} \mathrm{C}$, respectively. (b) Sugar standard curves $(0-10 \mu \mathrm{g} / \mathrm{mL})$. Data represent mean $\pm \mathrm{SEM}$ of four replicates. All $\left(R^{2}\right)>0.999$. Error bars where not visible are smaller than the data point. 
Table 3. Calibration curve data for sugar standards $(0.1-10 \mu \mathrm{g} / \mathrm{mL})$, separated and analyzed by HPAE-PAD.

\begin{tabular}{cccccccc}
\hline Sugar & $\begin{array}{c}\text { Retention } \\
\text { Time (min) }\end{array}$ & $\begin{array}{c}\text { Retention Time } \\
\text { Precision }(\mathbf{\% C V})\end{array}$ & $\begin{array}{c}\text { Calibration } \\
\text { Range }(\mu \mathbf{M})\end{array}$ & $\begin{array}{c}\text { Regression } \\
\text { Equation }\end{array}$ & $\begin{array}{c}\text { Correlation } \\
\text { Coefficient }\left(\mathbf{R}^{\mathbf{2}}\right)\end{array}$ & $\begin{array}{c}\text { LOD }^{\mathbf{1}} \\
(\boldsymbol{\mu M})\end{array}$ & $\begin{array}{c}\text { LOQ }^{\mathbf{1}} \\
(\mu \mathbf{M})\end{array}$ \\
\hline Glucose & 5.542 & 0.40 & $0.56-55.5$ & $\mathrm{y}=1.1540 \mathrm{x}+0.1366$ & 0.9991 & 0.5952 & 1.804 \\
\hline Sucrose & 6.842 & 0.60 & $0.29-29.2$ & $\mathrm{y}=0.3299 \mathrm{x}+0.0385$ & 0.9994 & 0.4797 & 1.454 \\
\hline Fructose & 7.808 & 1.05 & $0.56-55.5$ & $\mathrm{y}=0.5741 \mathrm{x}+0.8929$ & 0.9990 & 0.6190 & 1.876 \\
\hline Isomaltose & 10.975 & 0.50 & $0.29-29.2$ & $\mathrm{y}=0.7562 \mathrm{x}+0.0387$ & 0.9999 & 0.2004 & 0.607 \\
\hline Maltose & 19.492 & 0.93 & $0.29-29.2$ & $\mathrm{y}=0.6027 \mathrm{x}+0.0050$ & 1.0000 & 0.1056 & 0.320 \\
\hline
\end{tabular}

${ }^{1}$ LOD (limit of detection) and LOQ (limit of quantification) were confirmed by injections of sugar standards in the range listed and measuring responses at 3 and 10 times the noise, respectively $(\mathrm{LOD}=3.3 \times(\mathrm{STEYX} / \mathrm{SLOPE})$, and LOQ $=10 \times(\mathrm{STEYX} / \mathrm{SLOPE})$ ).

Intra- and inter-run precision was determined by analyzing the standards in triplicate in a single run on the same day and repeated on four different days within four months. Samples were kept at $4{ }^{\circ} \mathrm{C}$ at all times to avoid repeated freeze/thaw cycles or deterioration at RT. The mean peak areas and coefficients of variation $(\% \mathrm{CV})$ were calculated to determine the precision, as per ICH guidelines, [32] as presented in Table 4.

Table 4. Intra- and inter-run peak area precision for sugars in mixed standard solutions analyzed by HPAE-PAD.

\begin{tabular}{|c|c|c|c|c|c|c|c|c|c|c|}
\hline \multirow{2}{*}{$\begin{array}{c}\text { Sugar } \\
\begin{array}{c}\text { Concentration } \\
(\mu \mathrm{g} / \mathrm{mL})\end{array}\end{array}$} & \multicolumn{2}{|c|}{ Glucose } & \multicolumn{2}{|c|}{ Sucrose } & \multicolumn{2}{|c|}{ Fructose } & \multicolumn{2}{|c|}{ Isomaltose } & \multicolumn{2}{|c|}{ Maltose } \\
\hline & $\begin{array}{l}\text { Peak Area } \\
(\mathrm{nC} \times \text { min })\end{array}$ & $\% \mathrm{CV}$ & $\begin{array}{l}\text { Peak Area } \\
(\mathrm{nC} \times \text { min) }\end{array}$ & $\% \mathrm{CV}$ & $\begin{array}{l}\text { Peak Area } \\
(\mathrm{nC} \times \text { min })\end{array}$ & $\% \mathrm{CV}$ & $\begin{array}{l}\text { Peak Area } \\
(\mathrm{nC} \times \text { min) }\end{array}$ & $\% \mathrm{CV}$ & $\begin{array}{l}\text { Peak Area } \\
(\mathrm{nC} \times \text { min })\end{array}$ & $\% \mathrm{CV}$ \\
\hline \multicolumn{11}{|c|}{ Intra-run $(n=3)$-Repeatability } \\
\hline 0.1 & 0.13 & 2.14 & 0.04 & 5.52 & 0.07 & 6.52 & 0.08 & 3.47 & 0.05 & 10.39 \\
\hline 0.5 & 0.69 & 1.47 & 0.20 & 2.73 & 0.36 & 4.18 & 0.42 & 2.19 & 0.31 & 3.10 \\
\hline 1.0 & 1.38 & 1.21 & 0.39 & 1.56 & 0.70 & 2.20 & 0.84 & 1.63 & 0.62 & 2.17 \\
\hline 2.5 & 3.40 & 1.75 & 0.95 & 1.98 & 1.72 & 1.67 & 2.04 & 1.66 & 1.60 & 2.46 \\
\hline 5.0 & 6.59 & 1.36 & 1.82 & 1.43 & 3.27 & 1.63 & 3.99 & 1.48 & 3.16 & 1.35 \\
\hline 10.0 & 12.20 & 0.63 & 3.42 & 0.94 & 6.06 & 1.03 & 7.79 & 1.05 & 6.27 & 1.08 \\
\hline \multicolumn{11}{|c|}{ Inter-day $(n=12)$-Reproducibility } \\
\hline 0.1 & 0.12 & 12.44 & 0.04 & 7.03 & 0.06 & 10.22 & 0.08 & 5.14 & 0.06 & 12.78 \\
\hline 0.5 & 0.66 & 6.66 & 0.19 & 5.83 & 0.35 & 9.37 & 0.41 & 5.10 & 0.30 & 7.00 \\
\hline 1.0 & 1.29 & 7.55 & 0.37 & 4.34 & 0.67 & 7.69 & 0.80 & 4.84 & 0.60 & 5.40 \\
\hline 2.5 & 3.19 & 6.59 & 0.91 & 4.30 & 1.64 & 8.26 & 1.97 & 4.33 & 1.53 & 5.39 \\
\hline 5.0 & 6.17 & 6.14 & 1.74 & 3.60 & 3.06 & 7.99 & 3.85 & 4.15 & 3.03 & 4.71 \\
\hline 10.0 & 11.58 & 5.01 & 3.32 & 3.73 & 5.76 & 8.13 & 7.56 & 4.39 & 6.05 & 3.98 \\
\hline
\end{tabular}

Intra-run data collected from triplicate injections in a single run on 1 day; inter-run assays performed on four separate days in triplicate. The $\% \mathrm{CV}$ of peak areas were $<15 \%$, indicating excellent precision and recoveries.

The intra-day precision range was calculated to be $0.63-2.14 \%$ for glucose, $0.94-5.52 \%$ for sucrose, $1.03-6.52 \%$ for fructose, $1.05-3.47 \%$ for isomaltose and $1.08-10.39 \%$ for maltose, while inter-day evaluations were $5.01-12.44 \%, 3.73-7.03 \%, 8.13-10.22 \%, 4.39-5.14 \%$ and $3.98-12.78 \%$ for glucose, sucrose, fructose, isomaltose and maltose, respectively. Precision results were considered excellent, as they fall below $15 \%$ of ICH guidelines, even at the lowest sugar concentration of $0.1 \mu \mathrm{g} / \mathrm{mL}$. Extraction efficiency was between $95.9 \%$ and $108.9 \%$ for sucrose, maltose and isomaltose at two different concentrations, where the $\% \mathrm{RE}_{\text {accuracy }}$ and the $\% \mathrm{CV}_{\text {precision }}$ were $<10 \%$ for all concentrations (Table 5 ). 
Table 5. Extraction recoveries of maltose, sucrose and isomaltose added to assay buffer, analyzed by HPAE-PAD.

\begin{tabular}{|c|c|c|c|c|c|c|}
\hline \multirow{2}{*}{ Criteria } & \multicolumn{2}{|c|}{ Maltose } & \multicolumn{2}{|c|}{ Sucrose } & \multicolumn{2}{|c|}{ Isomaltose } \\
\hline & $\mathrm{C} 1$ & $\mathrm{C} 2$ & $\mathrm{C} 1$ & $\mathrm{C} 2$ & $\mathrm{C} 1$ & $\mathrm{C} 2$ \\
\hline $\begin{array}{l}\text { Post-assay concentration } \\
\text { recovered }(\mathrm{mM})\end{array}$ & $10.89 \pm 0.09$ & $19.18 \pm 0.23$ & $10.06 \pm 0.14$ & $21.35 \pm 0.30$ & $10.82 \pm 0.25$ & $21.38 \pm 0.28$ \\
\hline Extraction recovery $(\%)$ & $108.9 \pm 0.9$ & $95.9 \pm 1.1$ & $100.6 \pm 1.4$ & $106.9 \pm 1.7$ & $108.2 \pm 2.5$ & $106.9 \pm 0.6$ \\
\hline Relative error ${ }_{\text {accuracy }}\left(\% \mathrm{RE}_{\text {accuracy }}\right)$ & $8.93 \pm 0.94$ & $4.10 \pm 1.14$ & $1.96 \pm 0.30$ & $6.94 \pm 1.68$ & $8.24 \pm 2.49$ & $6.92 \pm 0.62$ \\
\hline $\begin{array}{l}\text { Coefficient of variance } \mathrm{precision} \\
(\% \mathrm{CV} \text { precision })\end{array}$ & 1.50 & 2.37 & 2.34 & 3.67 & 3.00 & 1.31 \\
\hline
\end{tabular}

All values are mean \pm SEM $(n=3)$. Pre-assay concentrations of maltose, sucrose and isomaltose spikes were $10 \mathrm{mM}(\mathrm{C} 1)$ and $20 \mathrm{mM}(\mathrm{C} 2)$. The $\% \mathrm{RE}_{\text {accuracy }}$ and $\% \mathrm{CV}$ precision values are $<10 \%$, demonstrating excellent recoveries.

Figure 2 displays the chromatogram of the sugar standards with efficient separation in a single 32-min elution, with good resolution. To analyze the efficiency of the enzyme reaction and sample extraction, substrates with or without cell-free extract (CFE) were digested, extracted and analyzed accordingly. The representative chromatograms in Figure 3 show the breakdown of sucrose into glucose and fructose (Figure 3a,b), and the breakdown of maltose (Figure 3c,d) and isomaltose (Figure 3d,e) into glucose was detectable with good resolution only when the relevant enzymes were present.

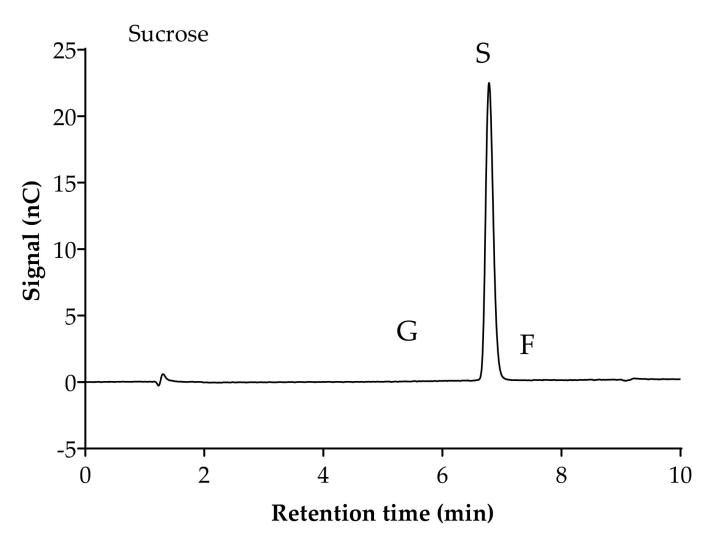

(a)

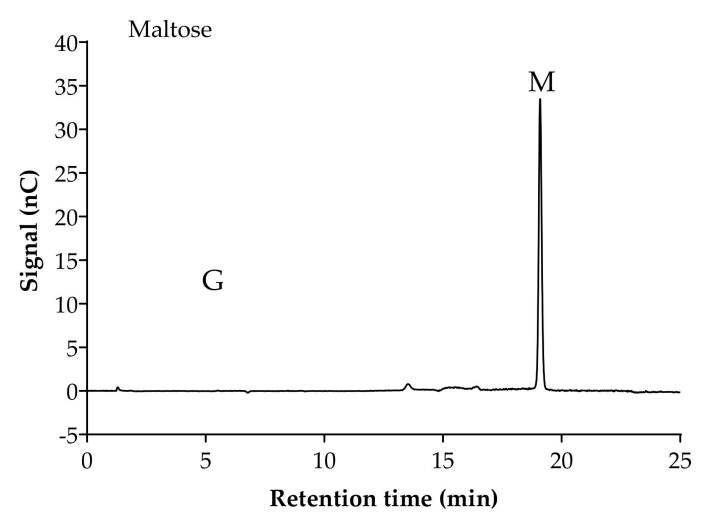

(c)

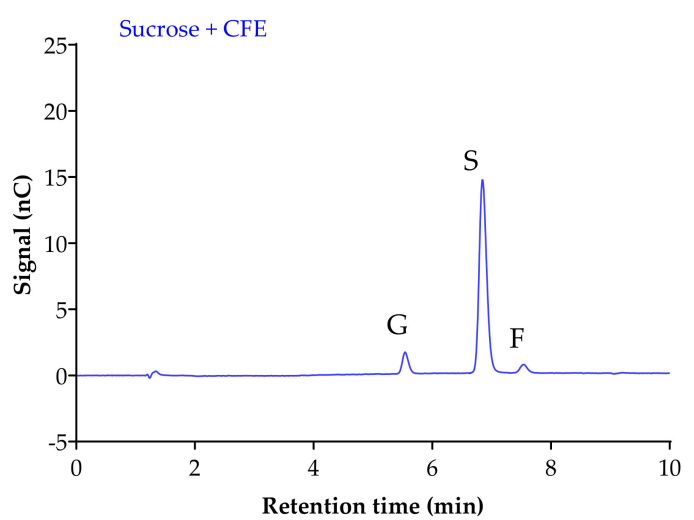

(b)

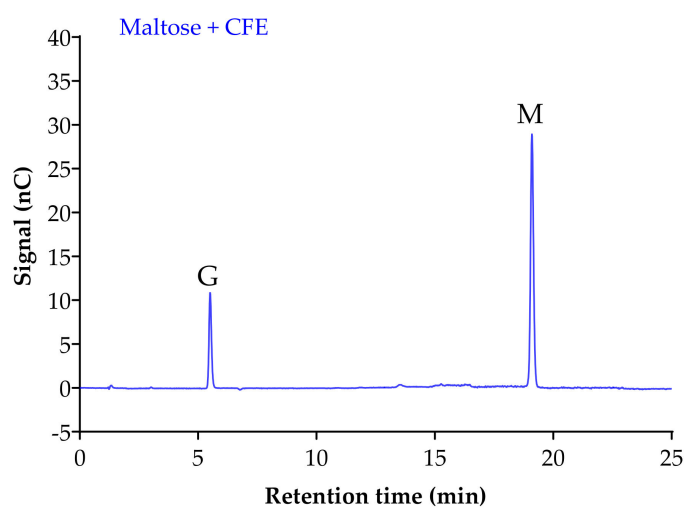

(d)

Figure 3. Cont. 


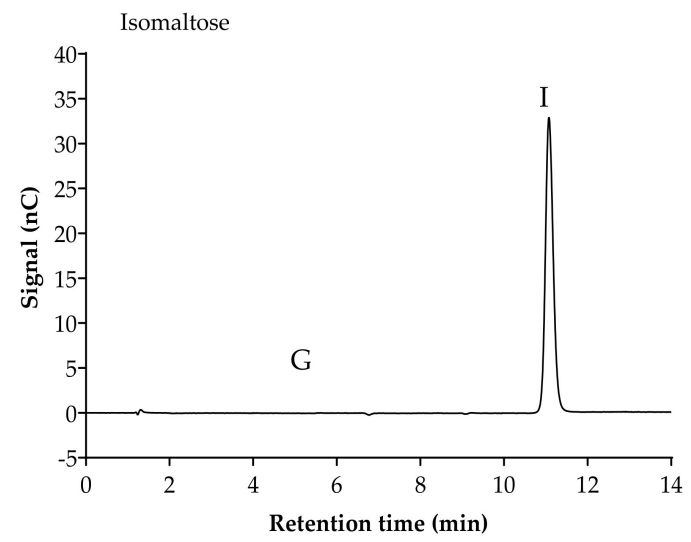

(e)

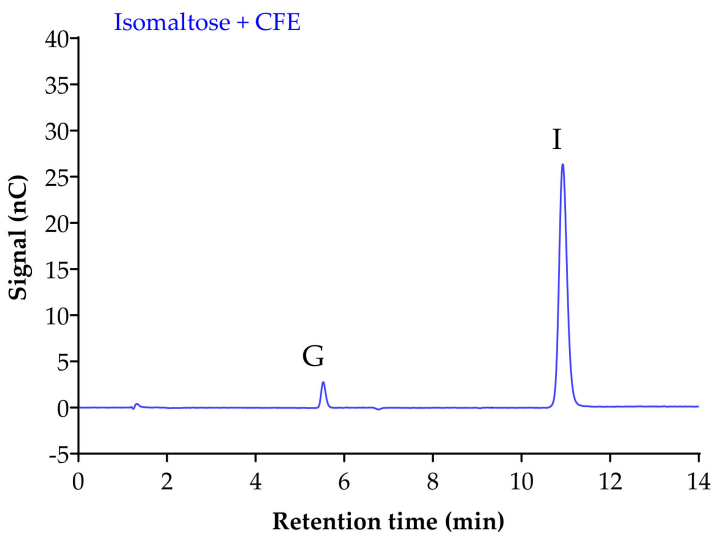

(f)

Figure 3. Representative chromatograms demonstrate the efficiency of sample digestion and extraction with or without $\alpha$-glucosidases from Caco-2/TC7 cell-free extract (CFE). Sucrose breakdown into glucose + fructose (a,b), and maltose $(\mathbf{c}, \mathbf{d})$ and isomaltose $(\mathbf{e}, \mathbf{f})$ breakdown into glucose is evident in the presence of enzymes. Sample digestion and extraction conditions: substrate $(20 \mathrm{mM}) \pm$ enzyme first incubated for enzyme reaction for $10 \mathrm{~min}$ at $37^{\circ} \mathrm{C}$, followed by second incubation for reaction termination for $10 \mathrm{~min}$ at $96^{\circ} \mathrm{C}$, then acetonitrile deproteination, sample dilution, sample injection and analysis by HPAE-PAD. Peaks were identified as glucose (G), sucrose (S), fructose (F), isomaltose (I) and maltose (M).

Table 6 indicates the peak areas of maltose, sucrose and isomaltose in the presence of (potential) inhibitors were not significantly different to when the compounds were not added (ANOVA: $\mathrm{F}<\mathrm{F}$ critical one tail, $p>0.05$ ), and without the presence of any additional glucose or fructose peaks in the chromatograms. High precision values were obtained for all tested sugars with inhibitors $\left(\% \mathrm{CV}_{\text {precision }}<15 \%\right)$, indicating no interference between sugars and tested substances. No peaks were observed in blank/control samples, where (potential) inhibitors, or assay buffer, or water, acetonitrile and eluent alone were tested.

Table 6. Comparison of peak areas of maltose, sucrose and isomaltose with and without acarbose or flavonoids.

\begin{tabular}{|c|c|c|c|c|}
\hline Sugar $(20 \mathrm{mM}) \pm$ Test Compounds & $n$ & Peak Area ${ }^{1}$ (nC $\times$ Time) & Precision $(\% \mathrm{CV})$ & One-Way ANOVA \\
\hline Maltose only & 9 & $5.37 \pm 0.29$ & $5.32 \%$ & \\
\hline Maltose + Acarbose & 6 & $4.91 \pm 0.46$ & $9.41 \%$ & \\
\hline Maltose + EGCG & 5 & $4.97 \pm 0.24$ & $4.73 \%$ & $F(6,29)=2.284$ \\
\hline Maltose + Quercetin & 4 & $5.02 \pm 0.06$ & $1.23 \%$ & F critical $=2.432$ \\
\hline Maltose + Quercetagetin & 4 & $5.15 \pm 0.12$ & $2.37 \%$ & $p$-value $=0.063$ \\
\hline Maltose + Kaempferol & 4 & $5.04 \pm 0.09$ & $1.78 \%$ & \\
\hline Maltose + Galangin & 4 & $5.36 \pm 0.43$ & $7.94 \%$ & \\
\hline Sucrose only & 10 & $2.97 \pm 0.14$ & $4.68 \%$ & \\
\hline Sucrose + Acarbose & 8 & $3.00 \pm 0.18$ & $5.83 \%$ & \\
\hline Sucrose + EGCG & 4 & $2.85 \pm 0.27$ & $9.53 \%$ & $\mathrm{~F}(6,48)=1.218$ \\
\hline Sucrose + Quercetin & 7 & $2.93 \pm 0.16$ & $5.37 \%$ & F critical $=2.295$ \\
\hline Sucrose + Quercetagetin & 3 & $2.97 \pm 0.04$ & $1.36 \%$ & $p$-value $=0.314$ \\
\hline Sucrose + Kaempferol & 5 & $3.09 \pm 0.05$ & $1.71 \%$ & \\
\hline Sucrose + Galangin & 7 & $3.01 \pm 0.12$ & $3.95 \%$ & \\
\hline Isomaltose only & 13 & $6.51 \pm 0.70$ & $10.73 \%$ & \\
\hline Isomaltose + Acarbose & 11 & $6.68 \pm 0.67$ & $10.11 \%$ & \\
\hline Isomaltose + EGCG & 10 & $6.36 \pm 0.18$ & $2.79 \%$ & $F(6,48)=1.218$ \\
\hline Isomaltose + Quercetin & 4 & $6.50 \pm 0.45$ & $6.86 \%$ & F critical $=2.295$ \\
\hline Isomaltose + Quercetagetin & 3 & $6.30 \pm 0.02$ & $0.32 \%$ & $p$-value $=0.314$ \\
\hline Isomaltose + Kaempferol & 7 & $6.96 \pm 0.29$ & $4.15 \%$ & \\
\hline Isomaltose + Galangin & 7 & $6.68 \pm 0.49$ & $7.29 \%$ & \\
\hline
\end{tabular}

${ }^{1}$ Values are mean $\pm \mathrm{SD}, n=$ technical replicates from biological CFE replicates of three. Acarbose and flavonoids were tested without enzymes at maximum concentrations: acarbose and quercetin, $200 \mu \mathrm{M}$; EGCG, $1500 \mu \mathrm{M}$; quercetagetin, $50 \mu \mathrm{M}$; kaempferol, $40 \mu \mathrm{M}$; galangin, $25 \mu \mathrm{M}$. 


\subsection{Inhibition of $\alpha$-Glucosidase Activities}

Based on the evidence that some flavonols consumed in the diet may reach concentrations as high as $50 \mu \mathrm{M}$ or more in the intestinal lumen [36], a concentration up to $200 \mu \mathrm{M}$, or maximal solubility, was used in this study. Where half-maximal inhibitory potential $\left(\mathrm{IC}_{50}\right)$ could not be determined, $\mathrm{IC}_{25}$ and $\mathrm{IC}_{15}$ were calculated instead. All flavonols, acarbose and EGCG inhibited $\alpha$-glucosidase activity to some extent (Figures 4-6 and Table 7).

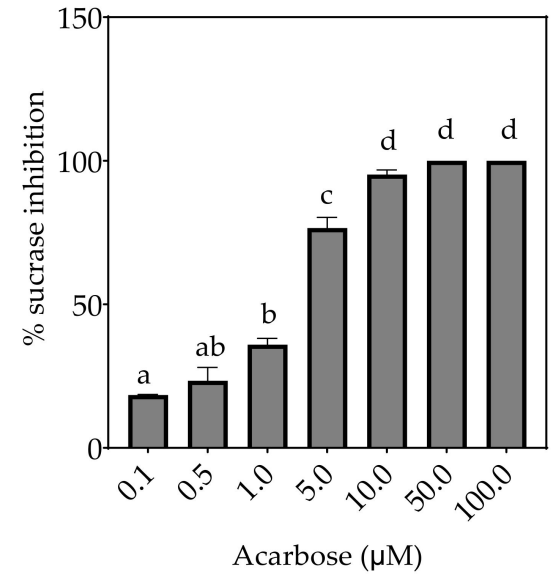

(a)

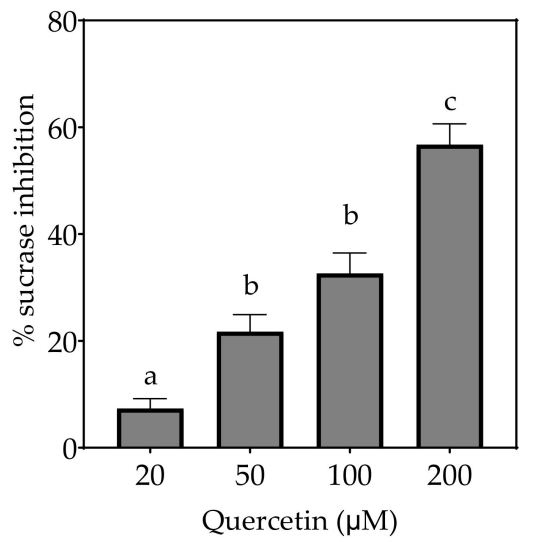

(c)

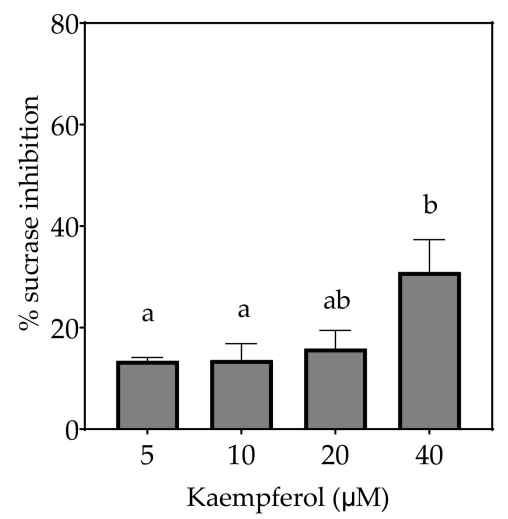

(e)

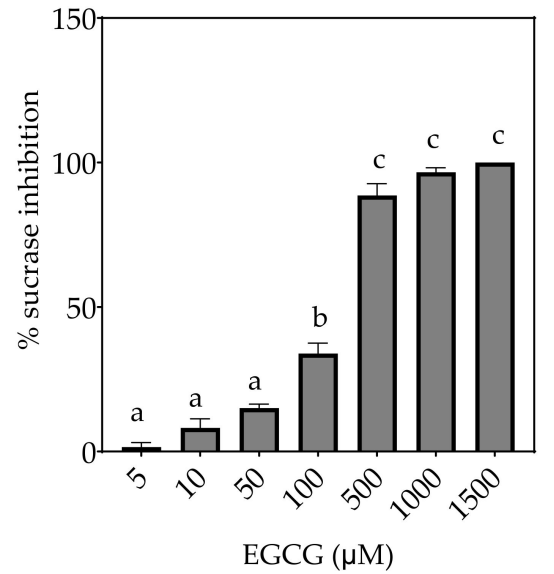

(b)

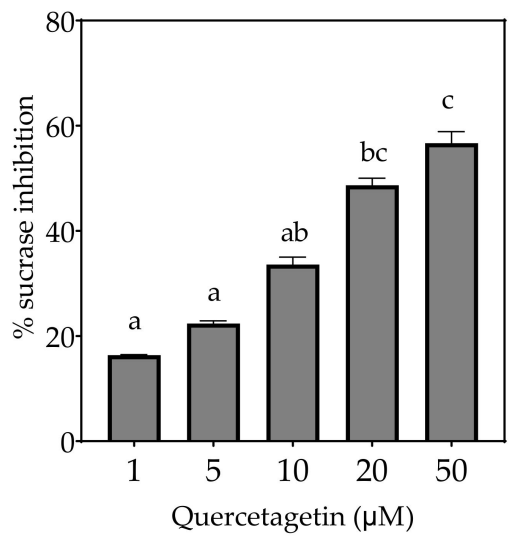

(d)

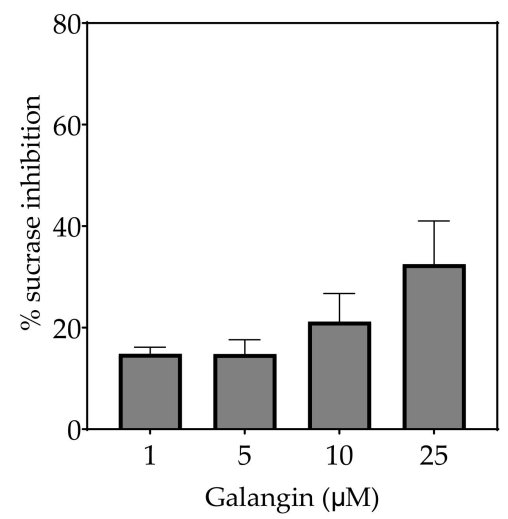

(f)

Figure 4. Inhibition of sucrase in Caco-2/TC7 cell-free extracts, using sucrose as the substrate, by (a) acarbose (positive control), (b) EGCG, (c) quercetin, (d) quercetagetin, (e) kaempferol and (f) galangin. Data are mean \pm SEM, $n \geq 2$ injections, for three different CFEs. Specific activity was calculated and relative inhibition was determined by comparing to the controls containing substrate and enzyme only. Values with different letters indicate significant differences $(p<0.05)$. 


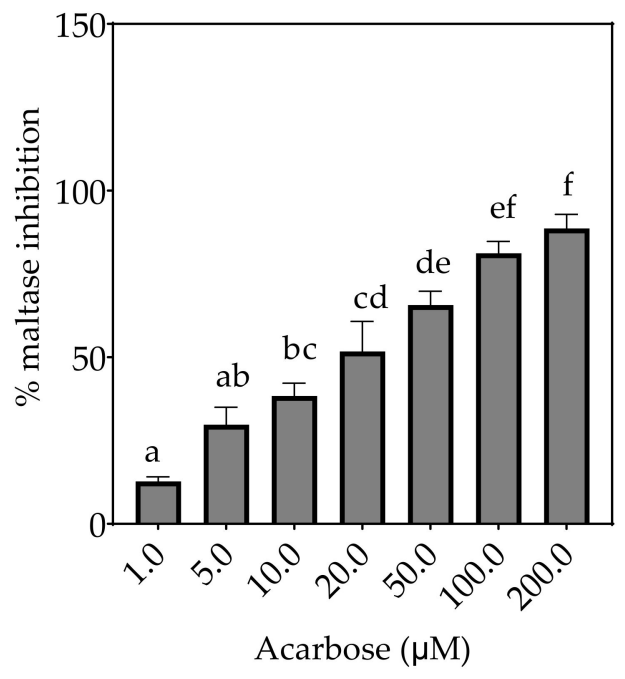

(a)

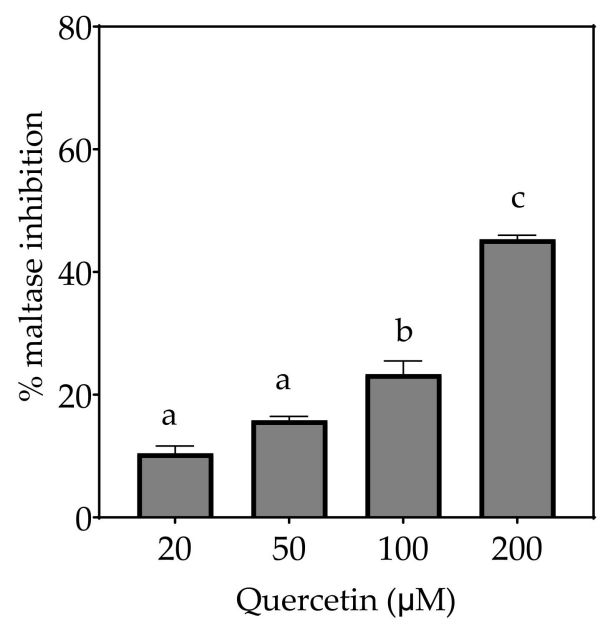

(c)

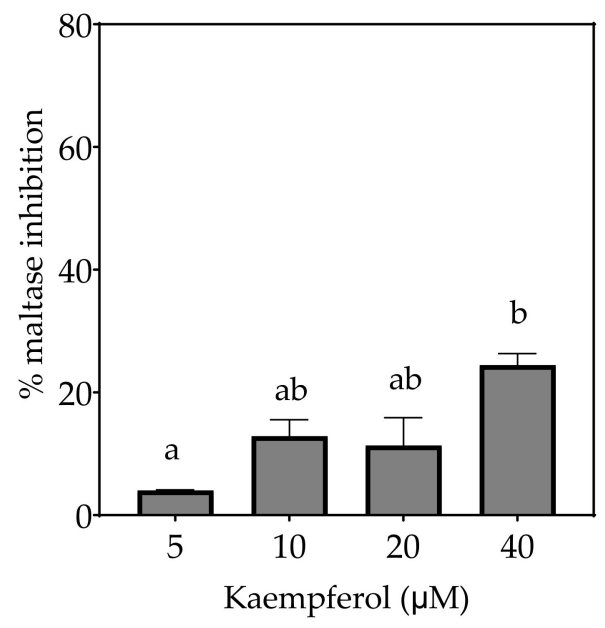

(e)

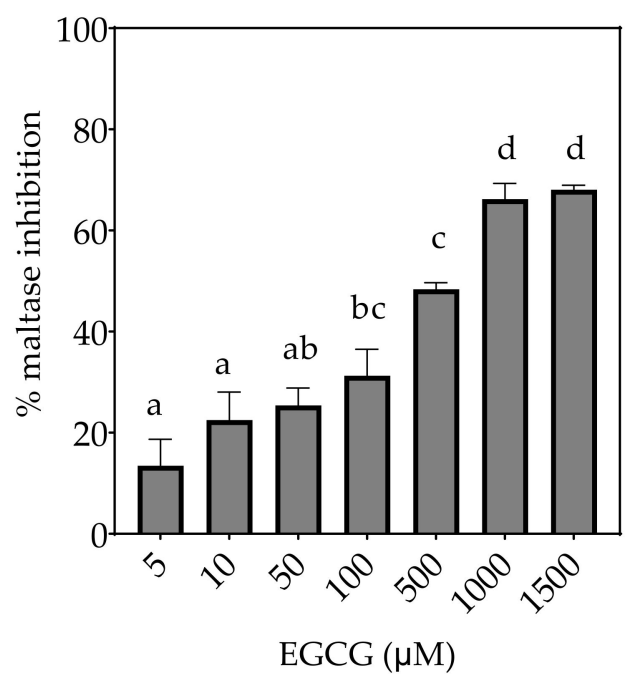

(b)

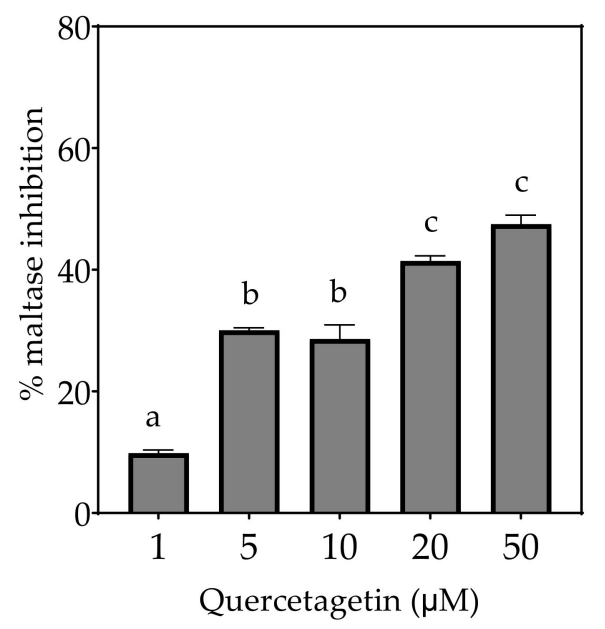

(d)

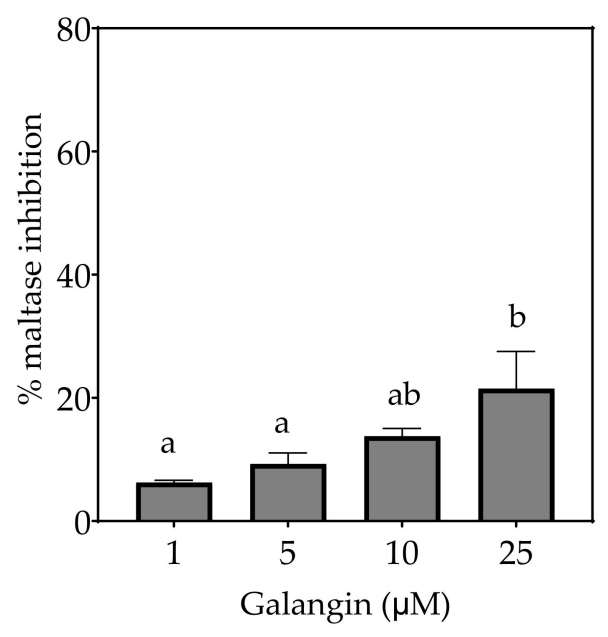

(f)

Figure 5. Inhibition of maltase in Caco-2/TC7 cell-free extracts, using maltose as the substrate, (a) acarbose (positive control), (b) EGCG, (c) quercetin, (d) quercetagetin, (e) kaempferol, and (f) galangin. Data are mean \pm SEM, $n \geq 2$ injections, for three different CFEs. Specific activity was calculated and relative inhibition was determined by comparing to the controls containing substrate and enzyme only. Values with different letters indicate significant differences $(p<0.05)$. 


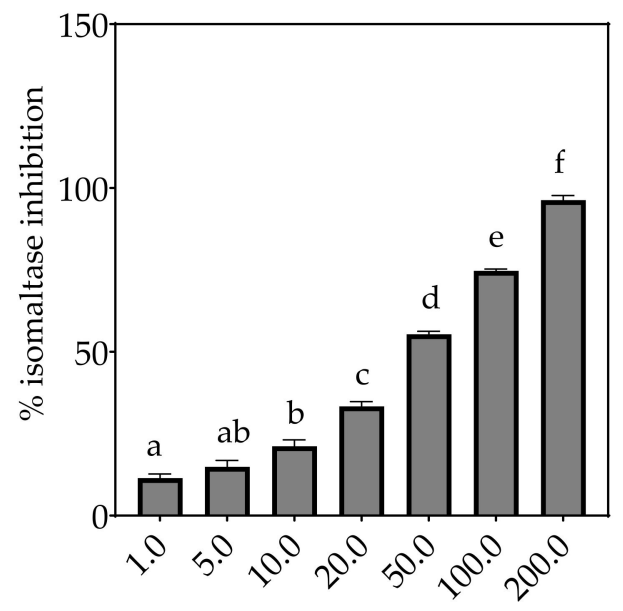

Acarbose $(\mu \mathrm{M})$

(a)

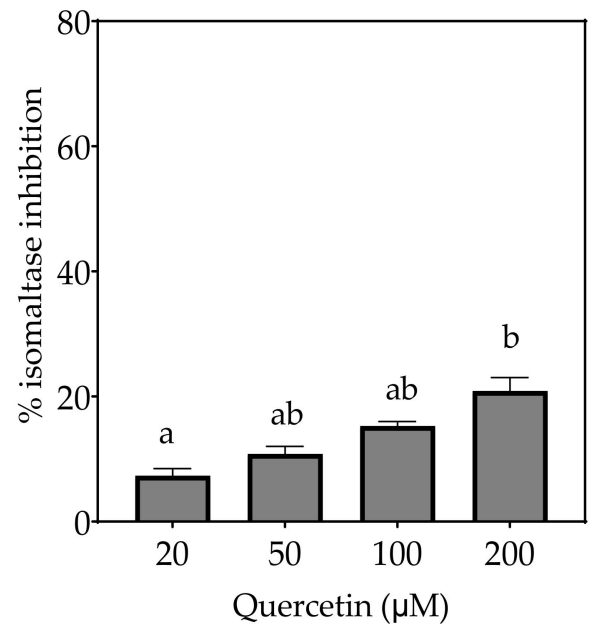

(c)

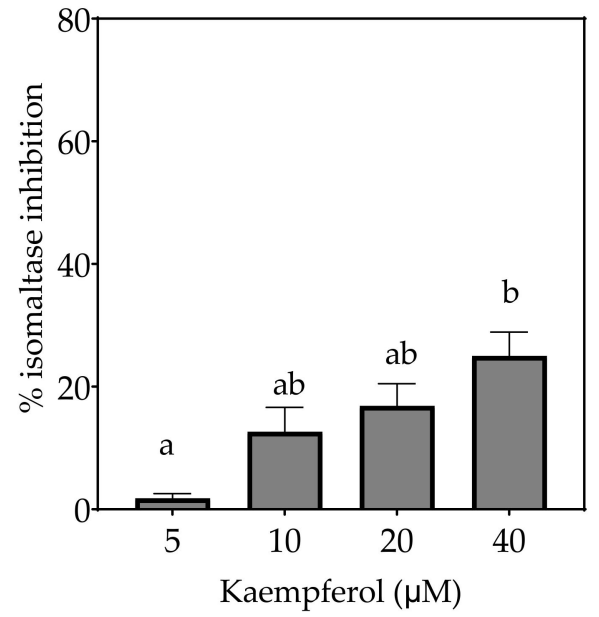

(e)

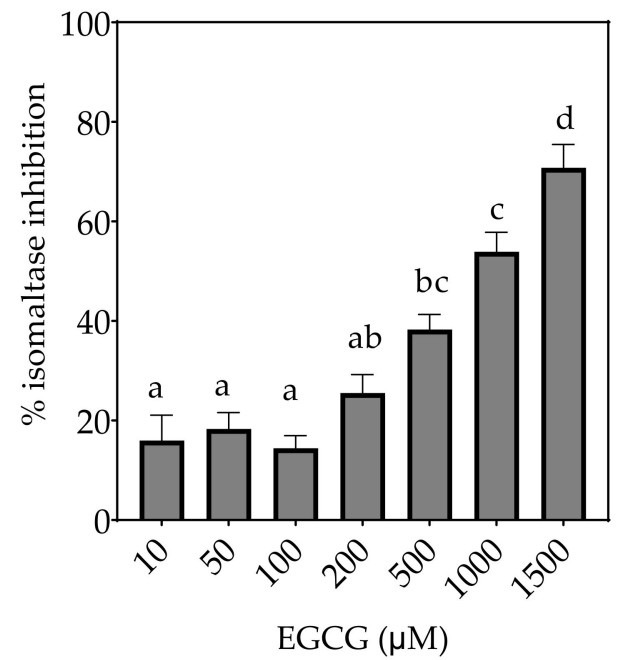

(b)

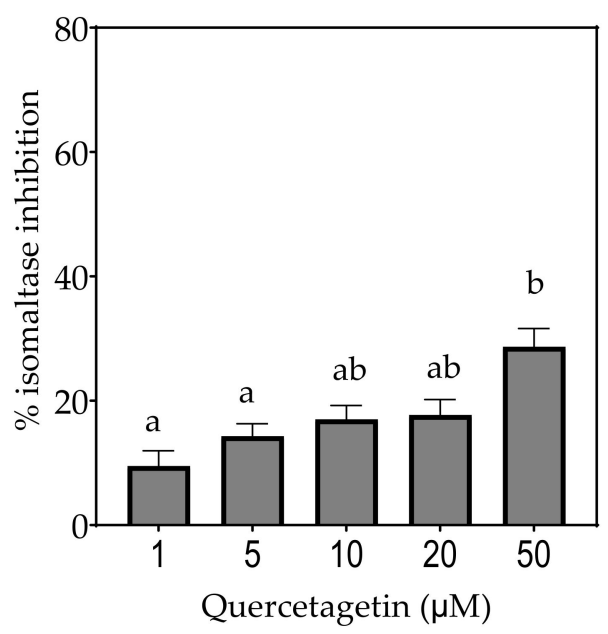

(d)

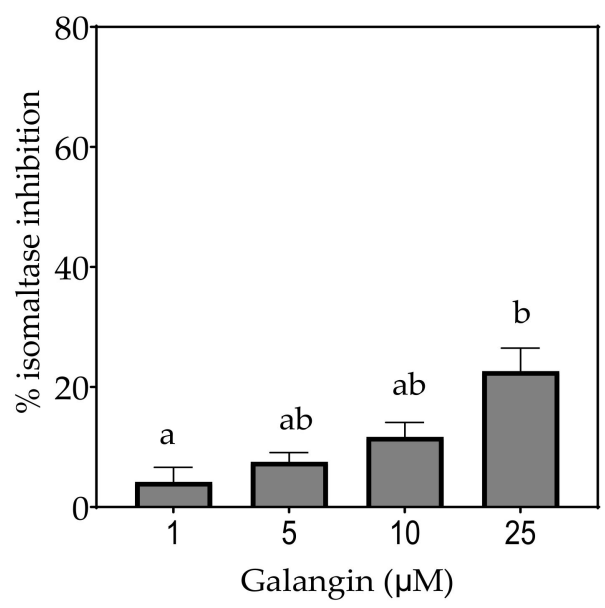

(f)

Figure 6. Inhibition of isomaltase in Caco-2/TC7 cell-free extracts, using isomaltose as the substrate, by (a) acarbose (positive control), (b) EGCG, (c) quercetin, (d) quercetagetin, (e) kaempferol and (f) galangin. Data are mean $\pm \mathrm{SEM}, n \geq 2$ injections, for three different CFEs. Specific activity was calculated and relative inhibition was determined by comparing to the controls containing substrate and enzyme only. Values with different letters indicate significant differences $(p<0.05)$. 
Table 7. Structures and inhibitory concentrations of acarbose and flavonoids in the human Caco-2/TC7 intestinal cell model.

\begin{tabular}{|c|c|c|c|c|c|c|}
\hline \multirow{2}{*}{ Compounds Tested } & \multirow{2}{*}{$\begin{array}{c}\text { Drug } \\
\text { Acarbose }\end{array}$} & \multirow{2}{*}{$\begin{array}{c}\text { Flavan-3-ol } \\
\text { EGCG }\end{array}$} & \multicolumn{4}{|c|}{ Flavonols } \\
\hline & & & Quercetin & Quercetagetin & Kaempferol & Galangin \\
\hline \multicolumn{2}{|c|}{ Chemical structure } & & & & & \\
\hline Molecular formula & $\mathrm{C}_{25} \mathrm{H}_{43} \mathrm{NO}_{18}$ & $\mathrm{C}_{22} \mathrm{H}_{18} \mathrm{O}_{11}$ & $\mathrm{C}_{15} \mathrm{H}_{10} \mathrm{O}_{7}$ & $\mathrm{C}_{15} \mathrm{H}_{10} \mathrm{O}_{8}$ & $\mathrm{C}_{15} \mathrm{H}_{10} \mathrm{O}_{6}$ & $\mathrm{C}_{15} \mathrm{H}_{10} \mathrm{O}_{5}$ \\
\hline Concentration $(\mu \mathrm{M})$ & $0-200^{1}$ & $0-1500^{1}$ & $0-200^{2}$ & $0-50^{2}$ & $0-40^{3}$ & $0-25^{3}$ \\
\hline \multicolumn{7}{|c|}{ Ring position and substitution } \\
\hline $\mathrm{C} 3, \mathrm{C}$ ring & - & galloyl & hydroxyl & hydroxyl & hydroxyl & hydroxyl \\
\hline $\mathrm{C} 5, \mathrm{~A}$ ring & - & $\mathrm{OH}$ & $\mathrm{OH}$ & $\mathrm{OH}$ & $\mathrm{OH}$ & $\mathrm{OH}$ \\
\hline C6, A ring & - & $\mathrm{H}$ & $\mathrm{H}$ & $\mathrm{OH}$ & $\mathrm{H}$ & $\mathrm{H}$ \\
\hline $\mathrm{C} 7, \mathrm{~A}$ ring & - & $\mathrm{OH}$ & $\mathrm{OH}$ & $\mathrm{OH}$ & $\mathrm{OH}$ & $\mathrm{OH}$ \\
\hline $\mathrm{C} 3^{\prime}, \mathrm{B}$ ring & - & $\mathrm{OH}$ & $\mathrm{OH}$ & $\mathrm{OH}$ & $\mathrm{H}$ & $\mathrm{H}$ \\
\hline $\mathrm{C} 4^{\prime}, \mathrm{B}$ ring & - & $\mathrm{OH}$ & $\mathrm{OH}$ & $\mathrm{OH}$ & $\mathrm{OH}$ & $\mathrm{H}$ \\
\hline $\mathrm{C} 5^{\prime}, \mathrm{B}$ ring & - & $\mathrm{OH}$ & $\mathrm{H}$ & $\mathrm{H}$ & $\mathrm{H}$ & $\mathrm{H}$ \\
\hline \multicolumn{7}{|c|}{$50 \%$ inhibitory concentration $\left(\mathrm{IC}_{50}\right)$} \\
\hline Sucrase $(\mu \mathrm{M})$ & $1.65 \pm 0.25^{\mathrm{a}}$ & $175.2 \pm 60.1^{c}$ & $161.9 \pm 13.6^{c}$ & $21.7 \pm 5.3^{b}$ & $\operatorname{ND}(31 \%)$ & $\mathrm{ND}(33 \%)$ \\
\hline Maltase $(\mu \mathrm{M})$ & $13.9 \pm 2.3^{a}$ & $186.4 \pm 40.4^{b}$ & $247.3 \pm 7.0^{b}$ & ND $(48 \%)$ & ND $(25 \%)$ & $\mathrm{ND}(22 \%)$ \\
\hline Isomaltase $(\mu \mathrm{M})$ & $39.1 \pm 2.1^{a}$ & $461.9 \pm 60.3^{b}$ & ND $(18 \%)$ & ND $(29 \%)$ & $\mathrm{ND}(27 \%)$ & ND $(22 \%)$ \\
\hline \multicolumn{7}{|c|}{$25 \%$ inhibitory concentration $\left(\mathrm{IC}_{25}\right)$} \\
\hline Sucrase $(\mu \mathrm{M})$ & $0.60 \pm 0.09^{a}$ & $72.9 \pm 10.3^{d}$ & $69.5 \pm 8.2^{d}$ & $6.6 \pm 1.8^{b}$ & $30.3 \pm 8.2^{c}$ & $20.8 \pm 5.5^{c}$ \\
\hline Maltase $(\mu \mathrm{M})$ & $4.6 \pm 0.8^{a}$ & $43.8 \pm 9.2^{b}$ & $82.0 \pm 4.6^{c}$ & $6.7 \pm 1.5^{\mathrm{a}}$ & $44.2 \pm 4.4^{b}$ & $17.6 \pm 2.2^{a}$ \\
\hline Isomaltase $(\mu \mathrm{M})$ & $14.4 \pm 1.1^{\mathrm{a}}$ & $241.9 \pm 40.4^{b}$ & ND $(18 \%)$ & $20.3 \pm 7.3^{a}$ & $34.0 \pm 8.4^{a}$ & $29.4 \pm 1.6^{a}$ \\
\hline \multicolumn{7}{|c|}{$15 \%$ inhibitory concentration $\left(\mathrm{IC}_{15}\right)$} \\
\hline Sucrase $(\mu \mathrm{M})$ & $0.32 \pm 0.05^{\mathrm{a}}$ & $41.2 \pm 6.0^{\mathrm{d}}$ & $40.5 \pm 5.1^{\mathrm{d}}$ & $3.5 \pm 1.1^{b}$ & $14.2 \pm 3.7^{c}$ & $12.7 \pm 2.1^{\mathrm{c}}$ \\
\hline Maltase $(\mu \mathrm{M})$ & $2.4 \pm 0.4^{\mathrm{a}}$ & $21.7 \pm 4.5^{\mathrm{c}}$ & $43.0 \pm 3.1^{\mathrm{d}}$ & $3.4 \pm 0.9^{\mathrm{ab}}$ & $19.0 \pm 5.5^{b c}$ & $8.7 \pm 1.1^{\mathrm{abc}}$ \\
\hline Isomaltase $(\mu \mathrm{M})$ & $7.8 \pm 0.7^{\mathrm{a}}$ & $118.6 \pm 18.0^{b}$ & $104.0 \pm 18.8^{b}$ & $5.9 \pm 1.9^{\mathrm{a}}$ & $12.5 \pm 3.7^{\mathrm{a}}$ & $9.3 \pm 1.2^{a}$ \\
\hline
\end{tabular}

IC values (mean \pm SEM, $n=3$ ) with different superscript letters in the same row indicate significant differences $(p<0.05$, nonparametric Kurskal-Wallis and Dunn's multiple comparison tests). Compounds soluble either ${ }^{1} \mathrm{SPB}$ buffer, ${ }^{2} \mathrm{DMSO}$ or ${ }^{3}$ ethanol. (ND) not determined, value in brackets indicates percent inhibition at maximum concentration tested. Flavonol skeletons show the numbering system of three rings $\mathrm{A}, \mathrm{B}$ and $\mathrm{C}$. Additional gallate group (D ring) is present in some flavan-3-ols.

\subsubsection{Sucrase}

On the basis of $\mathrm{IC}_{25}$ values, sucrase was inhibited in the order: acarbose $>$ quercetagetin $>$ galangin $\geq$ kaempferol $>$ quercetin $\geq$ EGCG (Table 7), with $>50 \%$ inhibition observed at the maximum tested concentrations of quercetin and quercetagetin (Figure 4).

\subsubsection{Maltase}

Based on the $\mathrm{IC}_{25}$ values, the decreasing order of the maltase inhibitory activity of the studied inhibitors was acarbose $\geq$ quercetagetin $\geq$ galangin $\geq$ kaempferol $\geq$ EGCG $>$ quercetin, where the significantly weakest inhibition of maltase was exhibited by quercetin $(p<0.05)$ (Table 7). Only acarbose and EGCG showed more than 50\% maltase inhibition at their maximal tested concentrations (Figure 5). 


\subsubsection{Isomaltase}

On the basis of the $\mathrm{IC}_{15}$ values, the decreasing order of the isomaltase inhibitory activity of the studied inhibitors was concluded to be quercetagetin $\geq$ acarbose $\geq$ galangin $\geq$ kaempferol $>$ quercetin $\geq$ EGCG. This pattern is almost identical to sucrase inhibition. The inhibition potentials of acarbose and EGCG were generally lower towards isomaltase than sucrase and maltase, where a few fold higher concentrations were required to exhibit half-maximal inhibition (Table 7). The inhibition shown by acarbose and EGCG was $96 \%$ and $71 \%$, respectively, while all flavonols exhibited $<30 \%$ inhibition of isomaltase (Figure 6).

\section{Discussion}

Flavonoids and other (poly)phenols potently inhibit $\alpha$-amylase and $\alpha$-glucosidase activities [37] without associated adverse gastrointestinal effects [38] and so may be useful in the management of T2D. However, previously, most inhibitory activities have been tested using $\alpha$-glucosidase from yeast (Saccharomyces cerevisiae) with limited reports on enzymes of mammalian or human origin [37]. Multiple $\alpha$-glucosidases are widely distributed in microorganisms, plants and animal tissues with variations in $>20$ amino acid sequences between species $[39,40]$. We explored disaccharide digestion in the human intestine by determining the inhibitory potential of flavonoids on sucrase, maltase and isomaltase in a specific mature Caco-2/TC7 clone, with high expression of SI [24]. Four flavonols were compared to a commercial $\alpha$-glucosidase inhibitor, acarbose and a flavan-3-ol, EGCG. All compounds inhibited human sucrase, maltase and isomaltase in a dose-dependent manner.

\subsection{Inhibitory Activities of Flavonoids}

\subsubsection{Quercetagetin}

Quercetagetin was first identified as part of spinacetin (quercetagetin-3',6-dimethyl ether) in spinach [41], and a few recent reports identified a possible function in glucose metabolism [42-45]. Compared to quercetin, it has an additional $\mathrm{C6}-\mathrm{OH}$ in the $\mathrm{A}$ ring, and exhibits various biological activities [46-48]. The additional $\mathrm{C} 6-\mathrm{OH}$ confers a strong affinity to proteins, speculated to weaken the binding of substrates to the active sites of enzymes and reduce or inhibit their activities [49]. Our study revealed quercetagetin as a strong human sucrase inhibitor, similar to acarbose and more potent than quercetin and EGCG. This was a greater inhibition than that seen previously against yeast $\alpha$-glucosidase [42], demonstrating the varied activities between species and substrates used. Quercetagetin could be a promising $\alpha$-glucosidase inhibitor, provided its high susceptibility to degradation [21] is considered.

\subsubsection{Kaempferol}

Kaempferol has one less hydroxyl group in the B ring than quercetin. It has consistently shown lower inhibition than quercetin against rat maltase [50-52], rat sucrase [51,52] and porcine pancreatic $\alpha$-amylase [50,52,53]. Inhibition of maltase by kaempferol (and galangin) was much less than that by acarbose in rats [54]. In contrast, kaempferol exhibited much stronger yeast $\alpha$-glucosidase inhibition (95\%) than acarbose [55-58], but weaker than quercetin [51,59]. In this study, kaempferol exhibited weaker inhibition of human sucrase, maltase and isomaltase than acarbose, with $<32 \%$ inhibition at $40 \mu \mathrm{M}$, but was better than quercetin. A kaempferol-rich extract exhibited notably different IC $_{50}$ values against human and yeast $\alpha$-glucosidases [60]. These comparisons indicate again the varied inhibitory potentials between species.

\subsubsection{Galangin}

Galangin has an unsubstituted B ring and is rich in many root plants, and possesses antiviral and anti-inflammatory properties with no toxic effects observed even at high doses in rats [61-63]. This compound regulates glucose homeostasis and enzymes responsible for glycolysis and gluconeogenesis in rats [64]. Reports have shown strong inhibition of 
$\alpha$-glucosidase in yeast, better than acarbose [65] but similar to kaempferol [66]. In contrast, both galangin and kaempferol were poorer maltase inhibitors than acarbose when tested using enzymes from rat intestine [54]. Like kaempferol, the poor aqueous solubility of the aglycone is a drawback for practical use.

\subsubsection{Quercetin}

Quercetin is a widely distributed flavonoid and therefore most researched in human and animal models. With a half-life of $\sim 24 \mathrm{~h}$ [67], a few fold increase of this compound in plasma after several weeks of ingestion was noted (reviewed in [68]). Quercetin is a potent inhibitor of intestinal GLUT2, substantially reducing glucose absorption [69]. Quercetin has repeatedly been reported to inhibit yeast $\alpha$-glucosidases more so than acarbose $[42,50,70-72]$. In contrast, for rat maltase and sucrase, it was shown to be weaker than acarbose $\left(\mathrm{IC}_{50}=281.2 \mu \mathrm{M}\right.$ for maltase, $\mathrm{IC}_{50}>400 \mu \mathrm{M}$ for sucrase) [52], similar to the data reported here.

\subsubsection{EGCG}

Among all tested flavonoids, while EGCG was most soluble with the highest inhibition reached for human sucrase $(100 \%)$, maltase $(68 \%)$ and isomaltase $(71 \%)$ at $1500 \mu \mathrm{M}$, this is a supra-physiological concentration and EGCG generally exhibited the weakest inhibitory potential when compared by concentration alone, as indicated previously [30]. Conversely, much stronger $\alpha$-glucosidase inhibitory effects were demonstrated against yeast or recombinant enzymes [73-75]. It has been suggested that EGCG (and quercetin) may exert much slower but more effective inhibition of disaccharide digestion in the intestine [75]. EGCG potently reduced glycaemic response in a diabetic animal model by binding to the active site of $\alpha$-amylase and $\alpha$-glucosidase [76] and decreased glucose uptake and GLUT2 expression in vitro [77]. However, a recent systematic review and meta-analysis from fourteen eligible articles demonstrated that the regular intake of EGCG-rich green tea had no significant effects on fasting blood glucose and insulin, HbA1c or HOMA-IR in T2D patients [78], which may be partially explained by the weak inhibition towards all three intestinal $\alpha$-glucosidases shown in this study.

\subsection{Structure-Function Relationships}

The most active flavonol was quercetagetin, with $\mathrm{IC}_{50}$ values closest to acarbose. This suggests that stronger enzyme inhibition is observed with increasing hydroxyls on the A ring since quercetagetin is a stronger inhibitor than quercetin. Increasing hydroxylation of the B ring (from galangin to kaempferol to quercetin) improves the solubility of compounds but lowers inhibition. The lower aqueous solubility of flavonols, observed in quercetagetin, kaempferol and galangin, is a shortcoming of this study, and is the reason why some $\mathrm{IC}_{50}$ values could not be determined.

At the molecular level, the binding between hydroxyls in ring A, B or C of flavonoids to the active sites of $\alpha$-glucosidases leads to structural changes in the enzyme evidenced by several docking studies with yeast $\alpha$-glucosidase $[20,55,72,79]$. The inhibitory activity of flavonoids was concluded to be in the decreasing order of anthocyanidin $\geq$ isoflavone $\geq$ flavonol $\geq$ flavone $\geq$ flavonone $\geq$ flavan-3-ol [50], indicating the crucial role of A ring hydroxylation for potent $\alpha$-glucosidases inhibition [80]. The A ring hydroxylation at C5 (fisetin converted to quercetin) or C6 (quercetin converted to quercetagetin) increased $\alpha$ glucosidase and $\alpha$-amylase inhibition in yeast and rat [50,81], and in human $\alpha$-glucosidases as shown here.

The hydroxylation patterns, particularly 3-OH at a B ring catechol moiety, are among the major determinants of various biological effects of flavonoids [82]. The hydrophilicity of compounds is enhanced with increasing hydroxyls in the B ring, which also affects $\alpha$-glucosidase inhibition, varying between species and substrates used $[20,83]$. The $\alpha$ glucosidase inhibitory activity of flavonols increased with increasing hydroxyls on the $\mathrm{B}$ ring in rat and yeast (myricetin > quercetin > kaempferol) [50,51], in contrast to the results 
shown in this study (quercetagetin > galangin > kaempferol > quercetin > EGCG), and again emphasizing the importance of using human enzymes. Further, the hydrogenation of the $\mathrm{C} 2$ = $\mathrm{C} 3$ double bond in flavan-3-ols on the $\mathrm{C}$ ring weakened their enzyme inhibition activities [50,80], despite higher binding affinities [84]. Saturated C2-C3 bonds in flavan3-ols are speculated to allow more twisting of the $\mathrm{B}$ ring and, together with additional hydroxyls on the gallate group in the $\mathrm{C}$ ring, increase solubility [85].

\subsection{Comparing Flavonoids to Acarbose}

Although mild $\alpha$-amylase inhibition is beneficial for blunting glucose spikes, excessive inhibition may induce starch indigestion and abnormal bacterial fermentation, causing abdominal pain, bloating or cramping [22]. Acarbose can induce these undesirable effects due to its potent inhibition of human and mammalian pancreatic $\alpha$-amylase [11]. Medicinal plant extracts containing quercetin and kaempferol consistently exhibited favorable inhibition against yeast and mammalian $\alpha$-glucosidase over pancreatic $\alpha$-amylase $[53,86-89]$. Many flavonoids have a higher inhibition of $\alpha$-glucosidases, leading to a slow-release effect, than of $\alpha$-amylase [75], which may be favoured over acarbose to decrease postprandial glucose spikes without the unpleasant side effects.

We have elucidated the inhibitory effects of flavonoids against human $\alpha$-glucosidases compared with acarbose, influenced by structure, enzyme origin and substrates. A higher concentration of acarbose is required to inhibit maltase than sucrase, while all flavonoids showed similar inhibition of sucrase and maltase, in agreement with our previous findings using olive leaf extracts [30]. Isomaltose is known to be hydrolyzed slowly by the SI complex, reflected by the accumulation of isomaltose in the intestine [90]. We have shown that quercetagetin (at higher concentrations) inhibits starch digestion through direct $\alpha$ amylase inhibition and starch complexation [91], making it a promising compound for regulating postprandial glycaemia.

Enzyme inhibition by plant extracts was consistently superior to acarbose when tested using yeast $\alpha$-glucosidase [72,73], in contrast to data on human or mammalian sucrase and maltase. Previously, an $\mathrm{IC}_{50}$ of $20 \mu \mathrm{M}$ for EGCG was determined for human maltase expressed in yeast [74], which is $8-10$-fold lower than reported here, and by us previously [30], using human intestinal Caco-2/TC7 as the enzyme origin. This emphasizes the importance of using a relevant substrate and enzyme source when screening for inhibitory potentials of compounds.

\section{Conclusions}

Our study highlights the potential of selected flavonoids to inhibit human intestinal $\alpha$ glucosidases, hence slowing carbohydrate digestion and reducing postprandial glycaemia. A sensitive and accurate method to determine sugar hydrolysis by sucrase, maltase and isomaltase has been successfully developed and validated. The use of HPAE-PAD to detect subtle changes in the concentrations of five sugars simultaneously, with minimal sample preparation and high precision within $32 \mathrm{~min}$, has been central to this study. Acarbose and flavonoids exhibit different inhibition of human enzymes to those reported for yeast or mammalian $\alpha$-glucosidases, emphasizing the need for a more pragmatic screening approach on individual human enzymes to elucidate their actual inhibitory potentials in vivo. Flavonoids from various sources are more effective against $\alpha$-glucosidase than $\alpha$-amylase [37]. The low solubility of some flavonoids limits the experimental concentration which can be employed, preventing the determination of $\mathrm{IC}_{50}$ values and necessitating the use of $\mathrm{IC}_{25}$ or $\mathrm{IC}_{15}$ values instead.

Quercetagetin, similar to acarbose, followed by kaempferol and galangin, exhibited greater inhibitory action against sucrase, maltase and isomaltase than EGCG and quercetin, although the latter compounds were more soluble in aqueous buffer. Two key structural elements of flavonoids for enhanced $\alpha$-glucosidase inhibition in humans are the $\mathrm{C6}-\mathrm{OH}$ A ring hydroxylation and reduced $\mathrm{B}$ ring hydroxylation. Improving understanding of how 
flavonoids bind to human $\alpha$-glucosidases should provide a rational basis for exploiting antidiabetic compounds from dietary sources.

Author Contributions: Conceptualization, E.B., M.J.H. and G.W.; methodology, M.J.H.; investigation, E.B. and M.J.H.; writing—original draft preparation, E.B.; writing—review and editing, E.B., M.J.H. and G.W.; supervision, G.W. All authors have read and agreed to the published version of the manuscript.

Funding: This research received no external funding.

Institutional Review Board Statement: Not applicable.

Informed Consent Statement: Not applicable.

Data Availability Statement: Not applicable.

Acknowledgments: We acknowledge Eglantine Balland and Asimina Kerimi for their essential contribution to setting up the lab, equipment and protocols.

Conflicts of Interest: The authors declare no conflict of interest.

\section{References}

1. Oguntibeju, O.O. Type 2 diabetes mellitus, oxidative stress and inflammation: Examining the links. Int. J. Physiol. Pathophysiol. Pharmacol. 2019, 11, 45-63. [PubMed]

2. Chiba, S. Molecular mechanism in alpha-glucosidase and glucoamylase. Biosci. Biotechnol. Biochem. 1997, 61, 1233-1239. [CrossRef] [PubMed]

3. Rose, D.R.; Chaudet, M.M.; Jones, K. Structural Studies of the Intestinal alpha-Glucosidases, Maltase-glucoamylase and Sucraseisomaltase. J. Pediatr. Gastroenterol. Nutr. 2018, 66 (Suppl. S3), S11-S13. [CrossRef] [PubMed]

4. Hamaker, B.R.; Lee, B.H.; Quezada-Calvillo, R. Starch digestion and patients with congenital sucrase-isomaltase deficiency. J. Pediatr. Gastroenterol. Nutr. 2012, 55 (Suppl. S2), S24-S28. [CrossRef]

5. Dahlqvist, A. Specificity of the human intestinal disaccharidases and implications for hereditary disaccharide intolerance. J. Clin. Investig. 1962, 41, 463-470. [CrossRef]

6. Karnsakul, W.; Luginbuehl, U.; Hahn, D.; Sterchi, E.; Avery, S.; Sen, P.; Swallow, D.; Nichols, B. Disaccharidase activities in dyspeptic children: Biochemical and molecular investigations of maltase-glucoamylase activity. J. Pediatr. Gastroenterol. Nutr. 2002, 35, 551-556. [CrossRef]

7. McIver, L.A.; Tripp, J. Acarbose. In StatPearls; StatPearls Publishing: Treasure Island, FL, USA, 2020.

8. Lin, W.H.; Yang, C.Y.; Kuo, S.; Kuo, T.H.; Roan, J.N.; Li, C.Y.; Wang, M.C.; Ou, H.T. Hepatic and cardiovascular safety of acarbose among type 2 diabetes patients with end-stage renal disease: A nationwide population-based longitudinal study. Diabetes Res. Clin. Pract. 2020, 108489. [CrossRef]

9. Li, C.; Kuang, J.; Zhao, Y.; Sun, H.; Guan, H. Effect of type 2 diabetes and antihyperglycemic drug therapy on signs of tumor invasion in papillary thyroid cancer. Endocrine 2020, 69, 92-99. [CrossRef]

10. DiNicolantonio, J.J.; Bhutani, J.; O'Keefe, J.H. Acarbose: Safe and effective for lowering postprandial hyperglycaemia and improving cardiovascular outcomes. Open Heart 2015, 2, e000327. [CrossRef]

11. Spiller, H.A. Management of antidiabetic medications in overdose. Drug Saf. 1998, 19, 411-424. [CrossRef] [PubMed]

12. Szymanska, R.; Pospisil, P.; Kruk, J. Plant-Derived Antioxidants in Disease Prevention 2018. Oxid. Med. Cell Longev. 2018, 2018, 2068370. [CrossRef] [PubMed]

13. Kim, Y.; Keogh, J.B.; Clifton, P.M. Polyphenols and Glycemic Control. Nutrients 2016, 8, 17. [CrossRef] [PubMed]

14. Aryaeian, N.; Sedehi, S.K.; Arablou, T. Polyphenols and their effects on diabetes management: A review. Med. J. Islam Repub. Iran 2017, 31, 134. [CrossRef] [PubMed]

15. Al-Duhaidahawi, D.; Hasan, S.A.; Al-Zubaidy, H.F.S. Flavonoids in the Treatment of Diabetes Clinical Outcomes and Mechanism to ameliorate Blood Glucose levels. Curr. Diabetes Rev. 2020. [CrossRef]

16. Scalbert, A.; Williamson, G. Dietary intake and bioavailability of polyphenols. J. Nutr. 2000, 130, 2073S-2085S. [CrossRef]

17. Manach, C.; Scalbert, A.; Morand, C.; Remesy, C. Polyphenols: Food sources and bioavailability. Am. J. Clin. Nutr. 2004, 79, 727-747. [CrossRef]

18. Rasouli, H.; Hosseini-Ghazvini, S.M.; Adibi, H.; Khodarahmi, R. Differential alpha-amylase/alpha-glucosidase inhibitory activities of plant-derived phenolic compounds: A virtual screening perspective for the treatment of obesity and diabetes. Food Funct. 2017, 8, 1942-1954. [CrossRef]

19. Woodward, K.A.; Draijer, R.; Thijssen, D.H.J.; Low, D.A. Polyphenols and Microvascular Function in Humans: A Systematic Review. Curr. Pharm. Des. 2018, 24, 203-226. [CrossRef] [PubMed]

20. Xiao, J.; Kai, G.; Yamamoto, K.; Chen, X. Advance in dietary polyphenols as alpha-glucosidases inhibitors: A review on structure-activity relationship aspect. Crit. Rev. Food Sci. Nutr. 2013, 53, 818-836. [CrossRef] 
21. Sun, Q.; Wedick, N.M.; Tworoger, S.S.; Pan, A.; Townsend, M.K.; Cassidy, A.; Franke, A.A.; Rimm, E.B.; Hu, F.B.; van Dam, R.M. Urinary Excretion of Select Dietary Polyphenol Metabolites Is Associated with a Lower Risk of Type 2 Diabetes in Proximate but Not Remote Follow-Up in a Prospective Investigation in 2 Cohorts of US Women. J. Nutr. 2015, 145, 1280-1288. [CrossRef]

22. Kumar, S.; Mittal, A.; Babu, D.; Mittal, A. Herbal medicines for diabetes management and its secondary complications. Curr. Diabetes Rev. 2020. [CrossRef]

23. Williamson, G. Possible effects of dietary polyphenols on sugar absorption and digestion. Mol. Nutr. Food Res. 2013, 57, 48-57. [CrossRef] [PubMed]

24. Van Beers, E.H.; Al, R.H.; Rings, E.H.H.M.; Einerhand, A.W.C.; Dekker, J.; Buller, H.A. Lactase and sucrase-isomaltase gene expression during Caco-2 cell differentiation. Biochem. J. 1995, 308, 769-775. [CrossRef] [PubMed]

25. Miyake, T.; Sakai, S.; Shibuya, T. Process for Producing a High-Purity Isomaltose. U.S. Patent 4,521,252, 26 October 1981.

26. Turco, L.; Catone, T.; Caloni, F.; Di Consiglio, E.; Testai, E.; Stammati, A. Caco-2/TC7 cell line characterization for intestinal absorption: How reliable is this in vitro model for the prediction of the oral dose fraction absorbed in human? Toxicol. In Vitro 2011, 25, 13-20. [CrossRef]

27. Pyner, A.; Nyambe-Silavwe, H.; Williamson, G. Inhibition of Human and Rat Sucrase and Maltase Activities To Assess Antiglycemic Potential: Optimization of the Assay Using Acarbose and Polyphenols. J. Agric. Food Chem. 2017, 65, 86438651. [CrossRef]

28. Amidon, G.L.; Lennernas, H.; Shah, V.P.; Crison, J.R. A theoretical basis for a biopharmaceutic drug classification: The correlation of in vitro drug product dissolution and in vivo bioavailability. Pharm. Res. 1995, 12, 413-420. [CrossRef] [PubMed]

29. Kaur, H.; Kaur, G. A Critical Appraisal of Solubility Enhancement Techniques of Polyphenols. J. Pharm. 2014, 2014. [CrossRef]

30. Pyner, A.; Chan, S.Y.; Tumova, S.; Kerimi, A.; Williamson, G. Indirect Chronic Effects of an Oleuropein-Rich Olive Leaf Extract on Sucrase-Isomaltase In Vitro and In Vivo. Nutrients 2019, 11, 1505. [CrossRef]

31. FDA. Guidance for Industry: Bioanalytical Method Validation; U.S. Department of Health and Human Services: Washington, DC, USA, 2018.

32. Branch, S.K. Guidelines from the International Conference on Harmonisation (ICH). J. Pharm. Biomed. Anal. 2005, 38, 798-805. [CrossRef]

33. Rao, T.N. Validation of Analytical Methods; IntechOpen: London, UK, 2018. [CrossRef]

34. Bradford, M.M. A rapid and sensitive method for the quantitation of microgram quantities of protein utilizing the principle of protein-dye binding. Anal. Biochem. 1976, 72, 248-254. [CrossRef]

35. Zor, T.; Selinger, S. Linearization of the Bradford Protein Assay Increases Its Sensitivity: Theoretical and Experimental Studies. Anal. Biochem. 1996, 236, 302-308. [CrossRef]

36. Walgren, R.A.; Walle, U.K.; Walle, T. Transport of quercetin and its glucosides across human intestinal epithelial Caco-2 cells. Biochem. Pharmacol. 1998, 55, 1721-1727. [CrossRef]

37. Zhu, J.; Chen, C.; Zhang, B.; Huang, Q. The inhibitory effects of flavonoids on alpha-amylase and alpha-glucosidase. Crit. Rev. Food Sci. Nutr. 2020, 60, 695-708. [CrossRef]

38. Sheliya, M.A.; Rayhana, B.; Ali, A.; Pillai, K.K.; Aeri, V.; Sharma, M.; Mir, S.R. Inhibition of alpha-glucosidase by new prenylated flavonoids from Euphorbia hirta L. herb. J. Ethnopharmacol. 2015, 176, 1-8. [CrossRef]

39. Hong, S.H.; Marmur, J. Upstream regulatory regions controlling the expression of the yeast maltase gene. Mol. Cell Biol. 1987, 7, 2477-2483. [CrossRef] [PubMed]

40. Hong, S.H.; Marmur, J. Primary structure of the maltase gene of the MAL6 locus of Saccharomyces carlsbergensis. Gene 1986, 41, 75-84. [CrossRef]

41. Zane, A.; Wender, S.H. Flavonols in spinach leaves. J. Org. Chem. 1961, 26, 4718-4719. [CrossRef]

42. Wang, W.; Xu, H.; Chen, H.; Tai, K.; Liu, F.; Gao, Y. In vitro antioxidant, anti-diabetic and antilipemic potentials of quercetagetin extracted from marigold (Tagetes erecta L.) inflorescence residues. J. Food Sci. Technol. 2016, 53, 2614-2624. [CrossRef] [PubMed]

43. Wu, Q.; Yang, X.; Zou, L.; Fu, D. Bioactivity guided isolation of alpha-glucosidase inhibitor from whole herbs of Crossostephium chinense. Zhongguo Zhong Yao Za Zhi 2009, 34, 2206-2211.

44. Xiao, X.; Erukainure, O.L.; Sanni, O.; Koorbanally, N.A.; Islam, M.S. Phytochemical properties of black tea (Camellia sinensis) and rooibos tea (Aspalathus linearis); and their modulatory effects on key hyperglycaemic processes and oxidative stress. J. Food Sci. Technol. 2020, 57, 4345-4354. [CrossRef] [PubMed]

45. Zou, L.; Wu, Q.; Yang, X.; Fu, D. Effects of chemical constituents of Crossostephium chinense on insulin secretion in rat islets in vitro. Zhongguo Zhong Yao Za Zhi 2009, 34, 1401-1405.

46. Gong, Y.; Liu, X.; He, W.H.; Xu, H.G.; Yuan, F.; Gao, Y.X. Investigation into the antioxidant activity and chemical composition of alcoholic extracts from defatted marigold (Tagetes erecta L.) residue. Fitoterapia 2012, 83, 481-489. [CrossRef]

47. Baek, S.; Kang, N.J.; Popowicz, G.M.; Arciniega, M.; Jung, S.K.; Byun, S.; Song, N.R.; Heo, Y.S.; Kim, B. Y.; Lee, H.J.; et al. Structural and functional analysis of the natural JNK1 inhibitor quercetagetin. J. Mol. Biol. 2013, 425, 411-423. [CrossRef]

48. Tereschuk, M.L.; Riera, M.V.; Castro, G.R.; Abdala, L.R. Antimicrobial activity of flavonoids from leaves of Tagetes minuta. J. Ethnopharmacol. 1997, 56, 227-232. [CrossRef]

49. Cotin, S.; Calliste, C.A.; Mazeron, M.C.; Hantz, S.; Duroux, J.L.; Rawlinson, W.D.; Ploy, M.C.; Alain, S. Eight flavonoids and their potential as inhibitors of human cytomegalovirus replication. Antiviral Res. 2012, 96, 181-186. [CrossRef] 
50. Tadera, K.; Minami, Y.; Takamatsu, K.; Matsuoka, T. Inhibition of alpha-glucosidase and alpha-amylase by flavonoids. J. Nutr. Sci. Vitaminol. 2006, 52, 149-153. [CrossRef]

51. Wang, H.; Du, Y.; Song, C.H. $\alpha$-Glucosidase and $\alpha$-amylase inhibitory activities of guava leaves. Food Chem. 2010, 123, 6-13. [CrossRef]

52. Zhang, B.W.; Li, X.; Sun, W.L.; Xing, Y.; Xiu, Z.L.; Zhuang, C.L.; Dong, Y.S. Dietary Flavonoids and Acarbose Synergistically Inhibit alpha-Glucosidase and Lower Postprandial Blood Glucose. J. Agric. Food Chem. 2017, 65, 8319-8330. [CrossRef]

53. Ye, X.P.; Song, C.Q.; Yuan, P.; Mao, R. $\alpha$-Glucosidase and $\alpha$ amylase inhibitory activity of common constituents from traditional Chinese medicine used for diabetes mellitus. Chin. J. Nat. Med. 2010, 8, 349-352. [CrossRef]

54. Matsui, T.; Kobayashi, M.; Hayashida, S.; Matsumoto, K. Luteolin, a Flavone, Does Not Suppress Postprandial Glucose Absorption Through an Inhibition of $\alpha$-Glucosidase Action. Biosci. Biotechnol. Biochem. 2002, 66, 689-692. [CrossRef] [PubMed]

55. Peng, X.; Zhang, G.; Liao, Y.; Gong, D. Inhibitory kinetics and mechanism of kaempferol on alpha-glucosidase. Food Chem. 2016, 190, 207-215. [CrossRef] [PubMed]

56. Renda, G.; Sari, S.; Barut, B.; Soral, M.; Liptaj, T.; Korkmaz, B.; Ozel, A.; Erik, I.; Sohretoglu, D. alpha-Glucosidase inhibitory effects of polyphenols from Geranium asphodeloides: Inhibition kinetics and mechanistic insights through in vitro and in silico studies. Bioorgan. Chem. 2018, 81, 545-552. [CrossRef] [PubMed]

57. Camaforte, N.A.P.; Saldanha, L.L.; Vareda, P.M.P.; Rezende-Neto, J.M.; Senger, M.R.; Delgado, A.Q.; Morgan, H.J.N.; Violato, N.M.; Pieroni, L.G.; Dokkedal, A.L.; et al. Hypoglycaemic activity of Bauhinia holophylla through GSK3-beta inhibition and glycogenesis activation. Pharm. Biol. 2019, 57, 269-279. [CrossRef] [PubMed]

58. Varghese, G.K.; Bose, L.V.; Habtemariam, S. Antidiabetic components of Cassia alata leaves: Identification through alphaglucosidase inhibition studies. Pharm. Biol. 2013, 51, 345-349. [CrossRef] [PubMed]

59. Chen, H.; Ouyang, K.; Jiang, Y.; Yang, Z.; Hu, W.; Xiong, L.; Wang, N.; Liu, X.; Wang, W. Constituent analysis of the ethanol extracts of Chimonanthus nitens Oliv. leaves and their inhibitory effect on alpha-glucosidase activity. Int. J. Biol. Macromol. 2017, 98, 829-836. [CrossRef] [PubMed]

60. Andrade, C.; Ferreres, F.; Gomes, N.G.M.; Gil-Izquierdo, A.; Bapia, S.; Duangsrisai, S.; Pereira, D.M.; Andrade, P.B.; Valentao, P. Gustavia gracillima Miers. flowers effects on enzymatic targets underlying metabolic disorders and characterization of its polyphenolic content by HPLC-DAD-ESI/MS(n). Food Res. Int. 2020, 137, 109694. [CrossRef] [PubMed]

61. Aloud, A.A.; Veeramani, C.; Govindasamy, C.; Alsaif, M.A.; El Newehy, A.S.; Al-Numair, K.S. Galangin, a dietary flavonoid, improves antioxidant status and reduces hyperglycemia-mediated oxidative stress in streptozotocin-induced diabetic rats. Redox Rep. 2017, 22, 290-300. [CrossRef]

62. Patil, K.K.; Meshram, R.J.; Dhole, N.A.; Gacche, R.N. Role of dietary flavonoids in amelioration of sugar induced cataractogenesis. Arch. Biochem Biophys 2016, 593, 1-11. [CrossRef]

63. Aloud, A.A.; Chinnadurai, V.; Govindasamy, C.; Alsaif, M.A.; Al-Numair, K.S. Galangin, a dietary flavonoid, ameliorates hyperglycaemia and lipid abnormalities in rats with streptozotocin-induced hyperglycaemia. Pharm. Biol. 2018, 56, 302-308. [CrossRef]

64. Aloud, A.A.; Chinnadurai, V.; Chandramohan, G.; Alsaif, M.A.; Al-Numair, K.S. Galangin controls streptozotocin-caused glucose homeostasis and reverses glycolytic and gluconeogenic enzyme changes in rats. Arch. Physiol. Biochem. 2020, 126, 101-106. [CrossRef]

65. Zeng, L.; Ding, H.; Hu, X.; Zhang, G.; Gong, D. Galangin inhibits alpha-glucosidase activity and formation of non-enzymatic glycation products. Food Chem. 2019, 271, 70-79. [CrossRef] [PubMed]

66. Sheng, Z.; Ai, B.; Zheng, L.; Zheng, X.; Xu, Z.; Shen, Y.; Jin, Z. Inhibitory activities of kaempferol, galangin, carnosic acid and polydatin against glycation and $\alpha$-amylase and $\alpha$-glucosidase enzymes. Food Sci. Technol. 2018, 53, 755-766. [CrossRef]

67. Hollman, P.C.; van Trijp, J.M.; Buysman, M.N.; van der Gaag, M.S.; Mengelers, M.J.; de Vries, J.H.; Katan, M.B. Relative bioavailability of the antioxidant flavonoid quercetin from various foods in man. FEBS Lett. 1997, 418, 152-156. [CrossRef]

68. Eid, H.M.; Haddad, P.S. The Antidiabetic Potential of Quercetin: Underlying Mechanisms. Curr. Med. Chem. 2017, 24, 355-364. [PubMed]

69. Kwon, O.; Eck, P.; Chen, S.; Corpe, C.P.; Lee, J.H.; Kruhlak, M.; Levine, M. Inhibition of the intestinal glucose transporter GLUT2 by flavonoids. FASEB J. 2007, 21, 366-377. [CrossRef]

70. Figueiredo-Gonzalez, M.; Grosso, C.; Valentao, P.; Andrade, P.B. alpha-Glucosidase and alpha-amylase inhibitors from Myrcia spp.: A stronger alternative to acarbose? J. Pharm. Biomed. Anal. 2016, 118, 322-327. [CrossRef]

71. Escandon-Rivera, S.; Gonzalez-Andrade, M.; Bye, R.; Linares, E.; Navarrete, A.; Mata, R. alpha-glucosidase inhibitors from Brickellia cavanillesii. J. Nat. Prod. 2012, 75, 968-974. [CrossRef]

72. Mujawdiya, P.K.; Kapur, S. Screening of Antioxidant and $\alpha$-Glucosidase Inhibitory Activities of Indian Medicinal Plants. Curr. Enzyme Inhib. 2020, 16, 145-154. [CrossRef]

73. Gao, J.; Xu, P.; Wang, Y.; Wang, Y.; Hochstetter, D. Combined effects of green tea extracts, green tea polyphenols or epigallocatechin gallate with acarbose on inhibition against alpha-amylase and alpha-glucosidase in vitro. Molecules 2013, 18, 11614-11623. [CrossRef]

74. Nguyen, T.T.H.; Jung, S.H.; Lee, S.; Ryu, H.J.; Kang, H.K.; Moon, Y.H.; Kim, Y.M.; Kimura, A.; Kim, D. Inhibitory effects of epigallocatechin gallate and its glucoside on the human intestinal maltase inhibition. Biotechnol. Bioprocess. Eng. 2012, 17, 966-971. [CrossRef] [PubMed] 
75. Simsek, M.; Quezada-Calvillo, R.; Ferruzzi, M.G.; Nichols, B.L.; Hamaker, B.R. Dietary phenolic compounds selectively inhibit the individual subunits of maltase-glucoamylase and sucrase-isomaltase with the potential of modulating glucose release. $J$. Agric. Food Chem. 2015, 63, 3873-3879. [CrossRef]

76. Li, X.; Li, S.; Chen, M.; Wang, J.; Xie, B.; Sun, Z. (-)-Epigallocatechin-3-gallate (EGCG) inhibits starch digestion and improves glucose homeostasis through direct or indirect activation of PXR/CAR-mediated phase II metabolism in diabetic mice. Food Funct. 2018, 9, 4651-4663. [CrossRef]

77. Ni, D.; Ai, Z.; Munoz-Sandoval, D.; Suresh, R.; Ellis, P.R.; Yuqiong, C.; Sharp, P.A.; Butterworth, P.J.; Yu, Z.; Corpe, C.P. Inhibition of the facilitative sugar transporters (GLUTs) by tea extracts and catechins. FASEB J. 2020, 34, 9995-10010. [CrossRef]

78. Asbaghi, O.; Fouladvand, F.; Gonzalez, M.J.; Ashtary-Larky, D.; Choghakhori, R.; Abbasnezhad, A. Effect of green tea on glycemic control in patients with type 2 diabetes mellitus: A systematic review and meta-analysis. Diabetes Metab. Syndr. 2020, 15, 23-31. [CrossRef]

79. Bansode, T.S.; Salalkar, B.K. Strategies in the design of antidiabetic drugs from Terminalia chebula using in silico and in vitro approach. MicroMedicine 2016, 4, 60-67.

80. Gao, H.; Kawabata, J. Importance of the B ring and its substitution on the alpha-glucosidase inhibitory activity of baicalein, 5,6,7-trihydroxyflavone. Biosci. Biotechnol. Biochem. 2004, 68, 1858-1864. [CrossRef]

81. Lo Piparo, E.; Scheib, H.; Frei, N.; Williamson, G.; Grigorov, M.; Chou, C.J. Flavonoids for controlling starch digestion: Structural requirements for inhibiting human alpha-amylase. J. Med. Chem. 2008, 51, 3555-3561. [CrossRef] [PubMed]

82. Wang, T.; Li, Q.; Bi, K. Bioactive flavonoids in medicinal plants: Structure, activity and biological fate. Asian J. Pharm. Sci. 2018, 113, 12-23. [CrossRef] [PubMed]

83. Li, H.; Song, F.; Xing, J.; Tsao, R.; Liu, Z.; Liu, S. Screening and structural characterization of $\alpha$-glucosidase inhibitors from hawthorn leaf flavonoids extract by ultrafiltration LC-DAD-MSn and SORI-CID FTICR MS. J. Am. Soc. Mass Spec. 2009, 20, 1496-1503. [CrossRef] [PubMed]

84. Xiao, J.; Kai, G.; Ni, X.; Yang, F.; Chen, X. Interaction of natural polyphenols with alpha-amylase in vitro: Molecular propertyaffinity relationship aspect. Mol. Biosyst 2011, 7, 1883-1890. [CrossRef] [PubMed]

85. Cao, H.; Chen, X. Structures required of flavonoids for inhibiting digestive enzymes. Anticancer Agents Med. Chem. 2012, 12, 929-939. [CrossRef]

86. Wang, L.; Liu, Y.; Luo, Y.; Huang, K.; Wu, Z. Quickly Screening for Potential alpha-Glucosidase Inhibitors from Guava Leaves Tea by Bioaffinity Ultrafiltration Coupled with HPLC-ESI-TOF/MS Method. J. Agric. Food Chem 2018, 66, 1576-1582. [CrossRef] [PubMed]

87. Wang, L.; Luo, Y.; Wu, Y.; Liu, Y.; Wu, Z. Fermentation and complex enzyme hydrolysis for improving the total soluble phenolic contents, flavonoid aglycones contents and bio-activities of guava leaves tea. Food Chem. 2018, 264, 189-198. [CrossRef]

88. El-Fadi, S.A.; Osman, A.; Al-Zohairy, A.M.; Dahab, A.A.; Abo El Kheir, Z.A. Asessment of Total Phenolic, Flavonoid Content, Antioxidant Potential and HPLC Profile of Three Moringa Species Leaf Extracts. Sci. J. Flowers Ornam. Plants 2020, 7, 53-70. [CrossRef]

89. Toma, A.; Makonnen, E.; Mekonnen, Y.; Debella, A.; Addisakwattana, S. Intestinal alpha-glucosidase and some pancreatic enzymes inhibitory effect of hydroalcholic extract of Moringa stenopetala leaves. BMC Complement. Altern Med. 2014, 14, 180. [CrossRef] [PubMed]

90. Lee, B.H.; Rose, D.R.; Lin, A.H.; Quezada-Calvillo, R.; Nichols, B.L.; Hamaker, B.R. Contribution of the Individual Small Intestinal alpha-Glucosidases to Digestion of Unusual alpha-Linked Glycemic Disaccharides. J. Agric. Food Chem. 2016, 64, 6487-6494. [CrossRef] [PubMed]

91. Visvanathan, R.; Houghton, M.J.; Williamson, G. Maltoheptaoside hydrolysis with chromatographic detection and starch hydrolysis with reducing sugar analysis: Comparison of assays allows assessment of the roles of direct alpha-amylase inhibition and starch complexation. Food Chem. 2021, 343, 128423. [CrossRef] 